\title{
Subterfuge and Manipulation: Type III Effector Proteins of Phytopathogenic Bacteria
}

\author{
Sarah R. Grant, ${ }^{1,2}$ Emily J. Fisher, ${ }^{1}$ \\ Jeff H. Chang, ${ }^{1,5}$ Beth M. Mole, ${ }^{3}$ \\ and Jeffery L. Dangl $1^{1,2,3,4}$
}

\begin{abstract}
${ }^{1}$ Department of Biology, ${ }^{2}$ Curriculum in Genetics, ${ }^{3}$ Department Microbiology and Immunology, ${ }^{4}$ Carolina Center for Genome Sciences, University of North Carolina, Chapel Hill, North Carolina 27599; email: sgrant@email.unc.edu, ejfisher@email.unc.edu, bmmole@med.unc.edu, dangl@email.unc.edu ${ }^{5}$ Department of Botany \& Plant Pathology, Center for Gene Research \& Biocomputing, Oregon State University, Corvallis, Oregon 97331; email: jeff.chang@science.oregonstate.edu
\end{abstract}

Annu. Rev. Microbiol. 2006. 60:425-49

First published online as a Review in Advance on June 5, 2006

The Annual Review of Microbiology is online at micro.annualreviews.org

This article's doi: 10.1146/annurev.micro.60.080805.142251

Copyright (c) 2006 by Annual Reviews. All rights reserved

$0066-4227 / 06 / 1013-0425 \$ 20.00$

\section{Key Words}

plant disease resistance, basal defense response, microbial pathogens, Pseudomonas syringae, innate immunity

\begin{abstract}
Diverse gram-negative bacteria deliver effector proteins into the cells of their eukaryotic hosts using the type III secretion system. Collectively, these type III effector proteins function to optimize the host cell environment for bacterial growth. Type III effector proteins are essential for the virulence of Pseudomonas syringae, Xanthomonas spp., Ralstonia solanacearum and Erwinia species. Type III secretion systems are also found in nonpathogenic pseudomonads and in species of symbiotic nitrogen-fixing Rbizobium. We discuss the functions of type III effector proteins of plant-associated bacteria, with an emphasis on pathogens. Plant pathogens tend to carry diverse collections of type III effectors that likely share overlapping functions. Several effectors inhibit host defense responses. The eukaryotic host targets of only a few type III effector proteins are currently known. We also discuss possible mechanisms for diversification of the suite of type III effector proteins carried by a given bacterial strain.
\end{abstract}




\section{Contents}

INTRODUCTION.............. 426

FUNCTIONS OF TYPE III

\section{EFFECTORS IN}

VIRULENCE

Subterfuge: Type III Secretion

Systems Deliver Proteins into

Host Cells that Interfere with

Defense Responses ...

Manipulation: Type III Effectors

Target Host Proteins and

Modify their Normal Cellular

Function ...

Distribution of Type III Effectors . 437

CONCLUSIONS............... 440

\section{INTRODUCTION}

TTSS: type III secretion system

Type III effector: protein delivered or translocated into host cells via the TTSS

Type III helper proteins: proteins secreted via the TTSS that do not enter the cytoplasm of the host cell

Harpins: proteins secreted in a type III-dependent manner but remain outside the host cell

Hop:

Hrp-dependent outer protein location (119). This prevents macrophagemediated phagocytosis of Yersinia that normally clears them from the blood (114). In contrast to these well-documented examples, the functions of most type III effector proteins from plant pathogenic bacteria are not as well characterized. Accumulating evidence suggests that each pathogen strain introduces a collection of type III effectors into host cells to disable host defenses, facilitating pathogen survival and dissemination.

The TTSS is structurally similar to the basal body of the flagellum but has additional components that facilitate host cell contact. The type III pilus spans the bacterial envelope, forms a conduit between the bacteria and the host membrane, and generates a pore to facilitate translocation of type III effector proteins into the host cell. Specialized chaperone proteins often guide incompletely folded type III effector proteins to the cytoplasmic face of the apparatus for ATP-dependent unwinding and entry into the TTSS (3). The regulation of expression, structure, assembly, and trafficking of the TTSS from plant and animal pathogens has been recently reviewed (58) and is not detailed here.

In addition to type III effectors, type III helper proteins needed for proper assembly of the pilus are secreted via the TTSS. Plant pathogens must penetrate the polysacchariderich host cell wall before the TTSS can contact the plasma membrane. They secrete helper proteins and harpins (5) into the extracellular milieu. Harpins can induce cell death if applied as purified proteins to host cells. They can form beta-barrel pores in the host membranes in vitro $(77,104)$ and are potentially involved in promoting access of the type III effectors to the host cytoplasm. Other secreted, but apparently not translocated, proteins include the Pseudomonas syringae proteins HrpW, HopAK1 (formerly HopPmaH), and HopAJ1 (HopPmaG) (27). We use the "unified nomenclature" here (80), with old names, when common, in parentheses. Among these, HrpW and HopAK1 have pectate lyase domains. HrpW also has an additional domain 
that can independently trigger host cell death in tobacco (28) and HopAJ1 has homology to transglycosylases (53). Hence, this set of helper proteins may have the capacity to locally degrade host cell walls at the tip of the extruding type III pilus, potentially facilitating access to the plasma membrane.

The genes for the TTSS, along with harpins, accessory helper proteins, and specific transcriptional regulatory proteins, are encoded in a cluster of linked operons with the marks of pathogenicity islands, including flanking tRNA genes and unique $\mathrm{G}+\mathrm{C}$ content (26). Genes for some translocated type III effectors flank the TTSS gene cluster in P. syringae and other plant pathogens (4). However, plant pathogen type III effector genes are also scattered throughout the chromosome and on plasmids $(7,27,61,113)$, often flanked by genes encoding their chaperone proteins. Like the TTSS genes, the type III effector genes bear marks of pathogenicity islands and tend to be located in unrelated chromosome positions in different isolates $(27,70)$.

Delivery of type III effectors into the host cell is essential for the successful life histories of many gram-negative plantassociated bacteria. Figure $\mathbf{1}$ presents a stylized plant associated with several plant pathogenic and symbiotic bacteria. P. syringae grows as an epiphyte on leaf surfaces (Figure 1a) (15). When these bacteria gain entry via wounds or stomata, they colonize the intercellular space (the apoplast) and cause leaf speck disease (Figure $1 \boldsymbol{b}$ ). Unlike several enteric pathogens, plant pathogens do not appear to penetrate vascular tissue. Infection of leaf apoplasts leads to a variety of symptoms, ranging from galls to leaf spots (91). Xanthomonas campestris pathovar (pv.) vesicatoria also inhabits leaf apoplasts and causes a leaf spotting disease that superficially resembles $P$. syringae (not shown). Erwinia species cause fire blight or soft rot disease (98, 125). Soft rot Erwinia secrete plant cell wall-degrading enzymes via the type II secretion system and colonize the macerated tissue

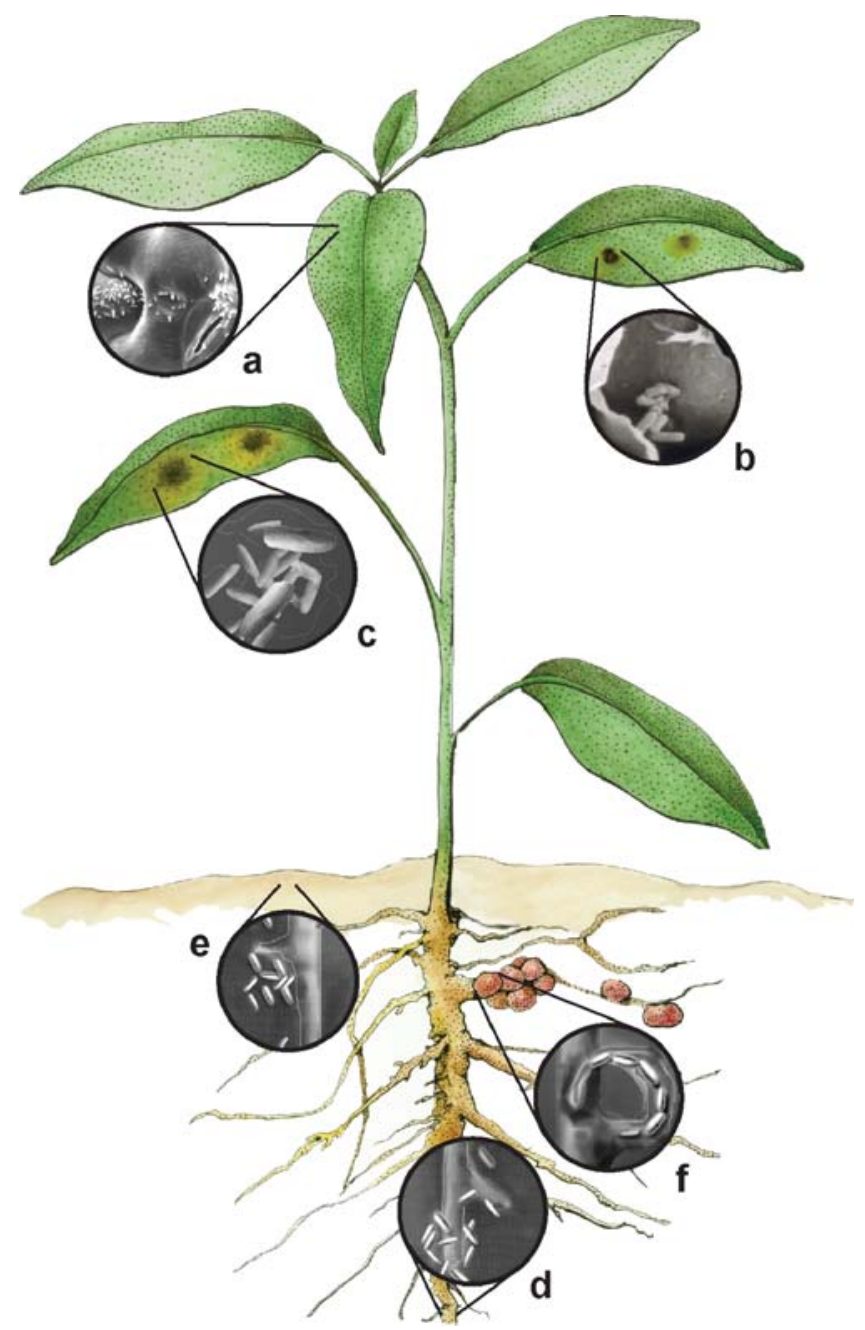

Figure 1

Both pathogenic and symbiotic plant associated bacteria have type III secretion systems. Sites of infection and plant symptoms with pathogenic or symbiotic bacteria are represented on an idealized plant. Pictures are not to scale. (a) Pseudomonas syringae growing as an epiphyte on a leaf surface next to a stomate (photo is from Gwyn Beattie, Iowa State University). (b) Scanning electron microscopy of $P$. syringae in apoplastic space within an infected leaf (reprinted, with permission, from Reference 96). (c) Erwinia carotovora atroseptica in an infected leaf. (d) Ralstonia solanacearum associated with a root. (e) Pseudomonas fluorescens on a root. ( $f$ ) Rbizobium spp. in a curling root hair. Nodules are illustrated on the indicated root.

(Figure 1c). Given their cell wall-degrading prowess, it is unclear why Erwinia would require a TTSS for colonization.

Some strains of biocontrol infect plants through the roots and colonizes the vascular
Pathovar (pv.): the host on which a plant pathogen isolate was collected 
PAMPs:

pathogen-associated molecular patterns

MAMPs:

microbe-associated molecular patterns

Programmed cell death (PCD): cell death induced by a stimulus is defined as programmed if cell signaling is required for cells to die tissue, causing a wilt disease (49) (Figure 1d). Some strains of biocontrol pseudomonads (Pseudomonas fluorescens and Pseudomonas putida) that associate with roots protecting plants against fungi and other bacteria also have TTSS genes (103) (Figure 1e). The same is true for some Rhizobium species that infect legumes through root hairs (Figure1 $f$ ). Inside the root, rhizobia establish root nodules where they fix atmospheric nitrogen into ammonia, which can be used as a nitrogen source by the plant (128). Because of their drastically different lifestyles, the nearly ubiquitous presence of TTSS and type III effectors in these species indicates that plant-associated microbes modulate a common mechanism, the host defense response.

The occurrence of TTSS in nonpathogenic pseudomonads and even in species of symbiotic nitrogen-fixing Rhizobium is at first glance odd, because we typically associate TTSS with pathogens. A TTSS is found in at least some strains of biocontrol pseudomonads (103, 108), but its necessity for association with plant roots is questionable. Mutations that inactivate the TTSS of $P$. $f u$ orescens strains SBW25 (103) or KD (107) do not interfere with normal root colonization. Other P. fluorescens strains that lack a TTSS are nonetheless successful root colonizers (101). A more intriguing role for TTSS in biocontrol pseudomonads was recently suggested by Rezzonico et al. (107), who proposed that biocontrol pseudomonads may actually target plant pathogens using a TTSS. P. fluorescens $\mathrm{KD}$ carrying a polar mutation in the TTSS-encoding gene cluster was less capable in protecting cucumber from Pythium ultimum, a fungus that causes damping-off disease.

In rhizobia, type III effectors that affect host range (87) and bacterial growth in some broad-host-range strains have been identified $(9,13,120)$. As with biocontrol pseudomonads, though, many Rhizobium strains apparently lack a TTSS but still are able to infect roots, form nodules, and fix nitrogen (86). Type III effector proteins in rhizobia are ex- pressed early in the root hair infection process $(73,128)$. Potentially, the initial stages of the molecular dialogue of host and bacteria require the latter to suppress host defense until it establishes itself in an "immune privileged" site such as a rhizobial bacteroid.

Diverse plant disease resistance mechanisms can be blocked by type III effector proteins, but type III effector proteins can also trigger the plant immune system. Plant defense mechanisms are based on three general levels of interdiction. The first is structural; most pathogens simply cannot begin their lifestyle on a particular plant surface. The second is guided by the plant's ability to recognize microbial molecular "patterns." These are collectively called pathogenassociated molecular patterns (PAMPs) or, more accurately, microbe-associated molecular patterns (MAMPs) (10). Recognition of these molecules, via specific receptors, induces a large host transcriptional reprogramming that consequently results in biosynthesis of structural barriers and antimicrobials. This response, by definition, is sufficient to stop the growth of nonpathogenic microbes; it is termed the basal defense response $(30,38,97,140)$. Pathogens, by definition, have evolved means to overcome basal defense. This can be deduced from the finding that type III pilus mutants, which no longer grow in planta, actually trigger a more rapid and higher amplitude basal defense response on disease-susceptible hosts compared with wild-type controls (62). Hence, bacterial pathogens use at least part of their type III effector protein collections as virulence factors to dampen or inhibit the plant's basal defense machinery.

However, the type III effectors that allow bacteria to be plant pathogens are a doubleedged sword, as plants have evolved a specific branch of their immune system to recognize type III effector action inside the host $(30,38)$. In fact, plant pathogen type III effector proteins were identified on the basis of their ability to elicit a particular form of host programmed cell death (PCD), called the 
hypersensitive response (HR), onto otherwise virulent pathogen strains. HR is determined by the activation of specific host proteins encoded by disease resistance genes. That type III effector proteins triggered HR was also demonstrated, in essence, by Lindgren et al. (81), who showed that the TTSS is essential for initiation of HR on disease-resistant hosts as well as for pathogenicity on diseasesusceptible hosts (34).

The majority of plant-specific disease resistance proteins share the structural properties of a nucleotide binding site followed by a variable number of leucine-rich repeats (LRRs). As a class, they are called nucleotide binding (NB)-LRR proteins $(30,38)$. The Arabidopsis genome encodes $\sim 125$ different NB-LRR proteins. Functional NB-LRR proteins recognize the presence of a specific bacterial type III effector protein during infection. Because plants are polymorphic for NB-LRR genes and pathogens are polymorphic for the type III effector genes that trigger their action, the interaction between bacterial avirulence ( $A v r$ ) genes and plant $R$ genes was called gene-for-gene resistance. While a receptor-ligand model easily explains this aspect of plant immune system genetics, there is little evidence to support it as a generality. By contrast, there is increasing evidence to suggest that the action of type III effector proteins indirectly activates the corresponding NB-LRR protein $(38,127)$. Examples of this model are detailed below.

Sequencing of complete bacterial genomes, coupled with a variety of effective genetic screens $(27,37,53,112,116)$, has led to the identification of large numbers of type III effectors in plant pathogens. These screens have been covered in several excellent recent reviews (5, 91, 96). More than 50 potential type III effector families have been identified in P. syringae alone (80). In this review, we survey what is known about the virulence functions of type III effector proteins, with an emphasis on those from $P$. syringae. We also examine the distribution of type III effector proteins in several sequenced bacterial genomes currently available in public databases.

The collection of type III effector proteins encoded by different species, or even in different strains within a species, is diverse. Because they are virulence factors, different type III effector proteins may be needed to facilitate distinct infection strategies or to manipulate plant-host-specific targets. Alternatively, at least part of the type III effector diversity may be caused by the need to avoid the plant immune system, as represented by the NBLRR proteins described above. The successful recognition of a type III effector's action by the corresponding NB-LRR protein has strong negative selective consequences across the microbial population. Hence, it is reasonable to suggest that type III effector diversity and distribution results from a balance between a requirement for multiple type III effector virulence functions to establish a successful infection on a given host species and the need to avoid the devastating consequences that arise if a single type III effector activates a NB-LRR protein in that host.

\section{FUNCTIONS OF TYPE III EFFECTORS IN VIRULENCE}

\section{Subterfuge: Type III Secretion Systems Deliver Proteins into Host Cells that Interfere with Defense Responses}

A functional TTSS is essential for $P$. syringae, $R$. solanacearum, Xanthomonas campestris pv. vesicatoria, and Erwinia amylovora to grow in plants $(6,14,20,81)$. The plant responds to TTSS-defective bacteria with a basal defense response involving rapid increases in $\mathrm{Ca}^{2+}$ flux and increases in nitric oxide and reactive oxygen species (97). Mitogen-activated protein kinase kinase (MAPKK) pathways are activated (8) and host transcription is dramatically altered $(40,124)$. Vesicle trafficking is activated, potentially leading to increased secretion of microcidal proteins and compounds and cell wall-strengthening components such
Hypersensitive response (HR): rapid programmed cell death that occurs at the site of infection if an $\mathrm{R}$ protein is activated

Specific disease resistance proteins: proteins activated to induce a strong defense response by the introduction of a specific type III effector protein into host cells

LRR: leucine-rich repeat

NB-LRR protein: nucleotide binding, leucine-rich repeat containing protein

$\boldsymbol{R}$ genes: encode specific disease resistance proteins 
SA: salicylic acid

LPS:

lipopolysaccharide

flg22: 22-amino-

acid flagellin peptide

Avirulence (Avr) protein: type III effector that activates a specific disease resistance protein as callose $(17,24,68)$. Autofluorescent papilla, rich in callose and phenolics, are produced in cell walls adjacent to infection sites. The plant hormone salicylic acid (SA), which is necessary to stimulate defense responses against biotrophic bacterial pathogens such as $P$. syringae, accumulates (50).

Basal defense responses can also be induced by application of PAMPs such as the purified 22-amino-acid flagellin peptide (flg22) (93, 142), lipopolysaccharide (LPS) derived from pathogen cell walls $(68,137)$, cold shock protein (48), and the bacterial translation factor EF-Tu (75). Specific receptors for flg22 (FLS2) (51) and EF-Tu have been identified in Arabidopsis (141). They are plasma-membrane-bound receptor kinases with extracellular LRRs. Host transcriptional changes induced by activation of the flg22 and EF-Tu receptors are largely overlapping (141). Type III effectors introduced via a functional TTSS appear to block all or parts of the constellation of host responses induced following PAMP perception.

Individual type III effectors interfere with particular defense responses. Deletion of single type III effector genes rarely affects the virulence of the strain in question $(56,130)$. This suggests that a given pathogen strain expresses functionally overlapping type III effectors that are not homologous, and hence likely represents convergent evolution driven by the need to manipulate a particular host target molecule. Alternatively, a given type III effector may simply not be functional on a given host plant and its gene may be maintained in the strain simply because it is evolutionarily neutral; that gene may still be of potential use on a different host sometime in the strain's future. Type III gene distribution may lead to a rephrasing of the old credo "that which does not kill you will make you stronger."

The lack of easily scored loss-of-function phenotypes for most type III effector mutants has made it difficult to assess their functions in disease. Recent studies have focused on spe- cific aspects of defense to investigate the function of type III effector proteins. These results are summarized in Table 1, and some are described below. Much of this work has been recently reviewed $(91,96)$. In summary, these experiments reveal that individual type III effectors alter some, but not all, aspects of either basal or NB-LRR-mediated specific defense responses. Sequence-unrelated type III effector proteins appear to overlap with respect to which aspects of defense response they can influence.

Some type III effectors block cell wallmediated defense responses. Callose deposition, a physical block to increased colonization, is stimulated in leaf mesophyll cells when Arabidopsis is exposed to P. syringae or $X$. campestris pv. vesicatoria mutants defective in type III secretion $(55,68)$ or to flg22 peptide (71). This defense response can be blocked by expression in trans of several type III effector proteins in those plant cells (Table 1). For example, the avirulence (Avr) protein AvrPto blocks papilla induced via an SAindependent pathway (55). Conditional expression of AvrPto in Arabidopsis leads to multiple changes in gene expression, including downregulation of secreted cell wall proteins. By contrast, the type III effector proteins AvrE and HopM1 (HopPtoM) block callose deposited as part of an SA-dependent response pathway. AvrE and HopM1 are functionally redundant but sequence unrelated (41). Deletion of both leads to a significant loss-ofpathogen virulence (at least for the strain tested), but complementation in the bacteria by either AvrE or HopM1 is sufficient to restore virulence of the double mutant to wildtype levels.

Some type III effectors manipulate plant hormone signaling to alter host defense responses. RAP2.6 is an ethyleneresponsive transcription factor in Arabidopsis. Its expression is induced following infection with virulent $P$. syringae via jasmonic acid (JA) signaling (56). JA is a signaling hormone 
Table 1 Type III effectors alter basal defense functions

\begin{tabular}{|c|c|c|c|c|}
\hline Defense function & Organism & Type III effector & Previous name & References \\
\hline Suppress papilla formation & $\begin{array}{l}\text { Pseudomonas } \\
\text { syringae }\end{array}$ & $\begin{array}{l}\text { AvrPto1 } \\
\text { AvrE1 } \\
\text { HopM1 } \\
\text { AvrRpm1 } \\
\text { AvrRpt2 }\end{array}$ & $\begin{array}{l}\text { AvrPto } \\
\text { AvrE } \\
\text { HopPtoM } \\
\text { AvrRpm1 } \\
\text { AvrRpt2 }\end{array}$ & $\begin{array}{l}55 \\
41 \\
71\end{array}$ \\
\hline Induce JA-responsive genes & P. syringae & $\begin{array}{l}\text { AvrB1 } \\
\text { AvrRpt2 } \\
\text { HopA1 } \\
\text { HopD1 } \\
\text { HopK1 } \\
\text { HopX1 } \\
\text { HopAO1 }\end{array}$ & $\begin{array}{l}\text { AvrB } \\
\text { AvrRpt2 } \\
\text { HopPsyA } \\
\text { HopPtoD1 } \\
\text { HopPtoK } \\
\text { AvrPphE } \\
\text { HopPtoD2 }\end{array}$ & 56 \\
\hline Alter ethylene responses & P. syringae & $\begin{array}{l}\text { AvrPto1 } \\
\text { HopAB2 }\end{array}$ & $\begin{array}{l}\text { AvrPto } \\
\text { AvrPtoB }\end{array}$ & 33 \\
\hline $\begin{array}{l}\text { Suppress cell death induced } \\
\text { by specific disease } \\
\text { resistance gene }\end{array}$ & P. syringae & $\begin{array}{l}\text { AvrRpm1 } \\
\text { AvrRpt2 } \\
\text { HopAB2 } \\
\text { AvrB2 } \\
\text { HopF2 } \\
\end{array}$ & $\begin{array}{l}\text { AvrRpm1 } \\
\text { AvrRpt2 } \\
\text { AvrPtoB } \\
\text { AvrPphC } \\
\text { AvrPphF } \\
\end{array}$ & $\begin{array}{l}110 \\
106 \\
2 \\
126\end{array}$ \\
\hline $\begin{array}{l}\text { Suppress cell death induced } \\
\text { in response to HopPsyA }\end{array}$ & P. syringae & $\begin{array}{l}\text { HopE1 } \\
\text { HopF2 } \\
\text { HopG1 } \\
\text { HopX1 } \\
\text { HopAB2 } \\
\text { HopAM1 }\end{array}$ & $\begin{array}{l}\text { HopE } \\
\text { HopF } \\
\text { HopG } \\
\text { AvrPphE } \\
\text { AvrPtoB } \\
\text { AvrPpiB } \\
\end{array}$ & 63 \\
\hline $\begin{array}{l}\text { Suppress cell death in } \\
\text { nonhost plant }\end{array}$ & P. syringae & $\begin{array}{l}\text { HopN1 } \\
\text { HopAB2 } \\
\text { HopAO1 } \\
\end{array}$ & $\begin{array}{l}\text { HopPtoN } \\
\text { AvrPtoB } \\
\text { HopPtoD2 } \\
\end{array}$ & $\begin{array}{l}82 \\
2,60 \\
22,47 \\
\end{array}$ \\
\hline $\begin{array}{l}\text { Suppress Flg22-dependent } \\
\text { NHO1 induction }\end{array}$ & P. syringae & $\begin{array}{l}\text { AvrPto1 } \\
\text { HopC1 } \\
\text { HopF2 } \\
\text { HopS1 } \\
\text { HopT1-1 } \\
\text { HopT1-2 } \\
\text { HopAA1-1 } \\
\text { HopAF1 } \\
\text { HopAI-1 } \\
\end{array}$ & $\begin{array}{l}\text { AvrPto } \\
\text { AvrPpiC2 } \\
\text { AvrPphF } \\
\text { HolPtoZ } \\
\text { HolPtoU1 } \\
\text { HolPtoU2 } \\
\text { HopPtoA1 }\end{array}$ & 78 \\
\hline
\end{tabular}

induced upon wounding or following infection with necrotrophic plant pathogens that rapidly kill host cells (50). JA and SA signaling can be antagonistic (74). Therefore, the activation of JA-induced signaling can repress the SA signaling pathway, which is necessary for effective basal defense against biotrophic pathogens such as $P$. syringae $(42,94,131)$. The P. syringae phytotoxin coronatine (COR) is a chemical mimic of JA and has the same effect (23). Five of 10 tested type III effector mutants of P. syringae pv. tomato (Pto) DC3000 exhibited significant loss of RAP2.6-induced expression (56) (Table 1). At least two other type III effectors, AvrB and AvrRpt2, induced RAP2.6 expression when expressed in a virulent $P$. syringae pathogen infecting susceptible Arabidopsis genotypes.
JA: jasmonic acid COR: coronatine 
Cohn \& Martin (33) used a cDNA microarray to analyze changes in gene expression in a susceptible tomato line in response to isogenic mutant strains of Pto DC3000 lacking either avrPto, hopAB2, or both. They found that both type III effectors regulate overlapping sets of genes involved in ethylene production and signaling, suggesting that AvrPto and HopAB2 perform similar functions in a compatible host. Ethylene is necessary for chlorotic disease symptom development, but its role in limiting bacterial growth is unclear.

Some type III effectors can interfere with programmed cell death induced by activation of disease resistance proteins. Specific disease resistance protein-mediated transcriptional outputs are similar in quality to responses induced by PAMPS or TTSSdefective bacteria, but are typically more rapid and of greater amplitude (33, 40, 93, 124). HR also nearly always accompanies disease resistance protein action (97). Type III effector proteins can interfere with HR activated following specific recognition of another type III effector protein, hence one can mask the other's presence. For example, HopAB1 (VirPphA) from P. syrinage pv. phaseolicola (60) can mask the presence of another type III effector that could otherwise trigger the function of a previously unidentified disease resistance protein. Agrobacterium-mediated transient expression of another HopAB family member, HopAB2 (AvrPtoB) from Pto DC3000 in tomato or tobacco cells, can block cell death induced by the interaction of a number of coexpressed $A v r$ and $R$ genes. It can also block cell death induced in tobacco or in yeast cells by coexpression of the nonspecific proapoptotic mouse protein Bax (2). Because it interferes with cell death initiated by several different stimuli, HopAB2 is thought to affect a late stage of the cell death pathway. However HopAB2 cannot block HR induced by all disease resistance proteins, and this activity requires its overexpression. For example, $P$. syringae that expresses HopAB2 is recognized by the tomato resistance pro- tein Pto, via the corresponding type III effector protein AvrPto, to induce a HR and an effective defense response.

The P. syringae type III effector HopF2 (AvrPphF) can inhibit cell death stimulated in bean cultivars by disease resistance proteins that are activated by other type III effector proteins from the same pathogen. In turn, AvrB2 (AvrPphC) inhibits cell death that is normally activated by HopF2 in bean cultivars that carry the appropriate disease resistance protein (126). Both AvrB2 and HopF2 may inhibit a late component of the cell death response, similar to the HopAB family members. Alternatively, they may interfere with activation of the specific disease resistance protein by the other type III effector. Such interference was initially described because P. syringae AvrRpm1 blocks HR elicited by AvrRpt2 and, when using different expression conditions, vice versa $(106,110)$. This occurs because both type III effectors interact with a common target called RIN4 (69). The same target is necessary for the activation of two different NB-LRR proteins, one activated by AvrRpt 2 and the other activated by AvrRpm1, as discussed further below. These results suggest that some type III effector gene combinations may be codistributed in order to negate the undesired activation of specific host disease resistance responses. In other words, some type III effectors may have virulence functions that block the avirulence functions of other type III effectors.

Some type III effectors can interfere with nonhost disease resistance. Several type III effector proteins can block nonhost-induced PCD initiated by expression of HopA1 (HopPsyA) in Nicotiana tabacum and Arabidopsis (63). With the exception of HopAM1 (AvrPpiB), they also inhibit PCD induced in yeast cells by coexpression of the nonspecific proapoptotic protein from mammalian cells, Bax1. This indicates that these type III effector proteins, like the HopAB family, block a nonspecific step of the PCD pathway. One important caveat from this work is that the 
type III effectors ascribed cell death suppression function are normally delivered from a virulent bacterial strain, Pto DC3000. This strain is nevertheless capable of triggering specific HR when it carries any of several type III effectors recognized as avirulence proteins by NB-LRR proteins in Arabidopsis. Hence, either the cell death suppression activities defined by Jamir et al. (63) act in pathways not involved in normal HR triggered by specific avirulence functions, or their action is diluted below a functional threshold when the signal for HR emanates from an activated NB-LRR protein.

HopAO1 (HopPtoD2) is an important example of another sort of type III effector protein-functional chimeras $(22,47)$. The HopAO1 C-terminal domain is homologous to a class of tyrosine phosphatases. Its Nterminal domain resembles another P. syringae type III effector with no predicted protein function called HopD (HopPtoD). Similar modular type III effectors with C-terminal protein phosphatase domains are found in Salmonella, SptP, and Yersinia, YopH (66). When expressed in P. syringae pv. phaseolicola, HopAO1 slows development of a nonhost HR in Nicotiana benthamiana (47). Mutations in the tyrosine phosphatase domain restore rapid cell death in this system, indicating that the slowing of cell death depends on the tyrosine kinase activity. Transient expression of an activated MAPKK, NtMEK ${ }^{\mathrm{DD}}$, in tobacco also leads to ectopic cell death (135). Coexpression of HopAO1 prevents this, again as long as the HopAO1 tyrosine phosphatase domain is functional. This could indicate that HopPtoD2 blocks HR downstream of NtMEK2 function. HopAO1 does not block HopA1 (HopPsyA)-induced cell death when both are delivered into host cells (63), indicating that a different step in PCD is involved.

Other type III effector proteins can alter parts of the host basal defense transcriptional output. For example, exposure of Arabidopsis to flg22 leads to induction of expression of NHO1 (78), a gene involved in nonhost resistance (65). Loss-of-function nho1 mutants allow nonhost $P$. syringae strains to grow on Arabidopsis, and overexpression of NHO1 enhances resistance to virulent Pto DC3000. Transgenic Arabidopsis plants expressing a NHO1-luciferase fusion protein were used to monitor the effects of individual type III effector proteins on flg22-induced NHO1 expression. They transfected protoplasts with 19 type III effectors from Pto DC3000 under the control of the strong constitutive $35 \mathrm{~S}$ viral promoter, exposed the protoplasts to $\mathrm{flg} 22$ peptide, and monitored the induction of luciferase. The nine type III effectors listed in Table 1 can block flg22-dependent activation of the NHO1 promoter (78).

\section{Manipulation: Type III Effectors Target Host Proteins and Modify their Normal Cellular Function}

The enzyme function of a small number of type III effectors has been predicted from homology to known proteins. Table 2 lists type III effector proteins from plant pathogens with known or predicted enzymatic function. Several types of proteases have been identified. P. syringae homologs to the Yersinia protease YopT include HopN1 (HopPtoN), HopAR1 (AvrPphB), and HopC1 (HopPtoC) $(25,83,119)$. Enzyme targets in plant hosts of the proteases HopAR1 (AvrPphB) and AvrRpt2 have also been identified and their role in plant defense is discussed below.

$X$. campestris pv. vesicatoria (91), P. syringae (7), R. solanacearum (43) and E. amylovora (98) have widely distributed type III effector proteins with homology to the Yersinia effector YopJ, which inhibits MAPK and Nfk-B signaling in pathogen-infected animal cells (99). Various SUMO proteases are found in $X$. campestris pv. vesicatoria. The YopJ family member AvrBsT has SUMO protease activity in vitro (100). A second YopJ family member, AvrXv4, can cleave SUMO modifications from multiple substrates in plants (91, 111), but a specific target has not been identified. Although they are members of the same
Nonhost

resistance: when all genotypes of a host mount a successful defense response against all genotypes of a pathogen

MAPK: mitogen-activated protein kinase 
Table 2 Type III effectors with known or predicted enzyme functions

\begin{tabular}{|c|c|c|c|c|}
\hline Function & Organism & Type III effector & Previous name & References \\
\hline $\begin{array}{l}\text { Papain-like cysteine protease, } \\
\text { YopT-like }\end{array}$ & Pseudomonas syringae & $\begin{array}{l}\text { HopC1 } \\
\text { HopN1 } \\
\text { HopAR1 }\end{array}$ & $\begin{array}{l}\text { HopPtoC } \\
\text { HopPtoN } \\
\text { AvrPphB }\end{array}$ & $\begin{array}{l}25 \\
82 \\
119,138 \\
\end{array}$ \\
\hline Staphopain cysteine protease & P. syringae & AvrRpt2 & AvrRpt2 & 32 \\
\hline $\begin{array}{l}\text { C48 family ubiquitin-like } \\
\text { SUMO protease }\end{array}$ & Xanthomonas campestris & XopD & XopD & 59 \\
\hline \multirow[t]{2}{*}{ YopJ-like SUMO protease } & P. syringae, $X$. campestris & $\begin{array}{l}\text { HopZ2 } \\
\text { AvrXv4 } \\
\text { AvrBsT } \\
\text { AvrRxv }\end{array}$ & $\begin{array}{l}\text { AvrPpiG } \\
\text { AvrXv4 } \\
\text { AvrBsT } \\
\text { AvrRxv }\end{array}$ & $\begin{array}{l}7 \\
111\end{array}$ \\
\hline & Ralstonia solanacearum & $\begin{array}{l}\text { PopP1 } \\
\text { PopP2 }\end{array}$ & $\begin{array}{l}\text { PopP1 } \\
\text { PopP2 }\end{array}$ & 43,76 \\
\hline Protein tyrosine phosphatase & P. syringae & HopAO1 & HopPtoD2 & 47 \\
\hline Ubiquitin E3 ligase & P. syringae & $\begin{array}{l}\text { HopAB2 } \\
\text { C terminus }\end{array}$ & AvrPtoB & 64 \\
\hline Transcription factor & Xanthomonas spp. & AvrBs3/PthA family & AvrBs3/PthA family & 123,134 \\
\hline $\begin{array}{l}\text { Glycerophosphoryl diester } \\
\text { phosphodiesterase }\end{array}$ & X. campestris pv. vesicatoria & AvrBs2 & AvrBs2 & 122 \\
\hline Syringolide synthase & P. syringae & AvrD1 & AvrD & 89 \\
\hline
\end{tabular}

protein family as YopJ, there is no evidence that they affect MAPK signaling in plants. XopD is a highly diverged, c48 family ubiquitin-like SUMO protease, and its activity in plant substrates has also been demonstrated in vitro (59).

HopAB family members (Tables 1 and 2 ) share at least an N-terminal homology of unknown function. The related HopAB1 and HopAB2 subfamilies (exemplified by VirPphA and AvrPtoB, respectively) also share related C-terminal domains. The $\mathrm{C}$ terminus of HopAB2 encodes a functional U-box E3 ubiquitin ligase (64). This domain is necessary and sufficient for the cell death inhibition function detailed below. Oddly, some HopAB3 subfamily members, such as P. syringae HopPmaL and HopPmaN, contain truncated $\mathrm{C}$ termini that lack the E3 ligase domain (79). The function of these truncated family members is unclear. These comparative analyses suggest that bacterial pathogens have genetic mechanisms to mix and match domains that might provide selective broadening of the host target range while conserving a basic function. One can imagine that the HopAB family shares an N- terminal domain to grab a particular host protein(s), and these targets, once bound, might be subjected to different fates depending on the C-terminal domain present in the particular HopAB subfamily in question.

The AvrBs3/PthA family of type III effector proteins is widely distributed in Xanthomonas species (26, 67, 136, 139). AvrBs3/PthA family members have features of transcription factors. Their $\mathrm{C}$ termini contain an acidic activation domain and three nuclear localization sites. A family member from Xanthomonas oryzae pv. oryzae, Xa7, binds ATrich DNA (134), but specific host DNA binding sites have not been identified. The acidic activation domain of Xa10 can activate transcription in yeasts and Arabidopsis (139). The family is also defined by a series of 34 base pair repeats encoding the central portion of the protein. The number of repeats can have functional consequences, though it is not understood how these differences are achieved. AvrBs3 interacts with $\alpha$-importin, as expected if it is transferred to the host nucleus (123). Simultaneous deletion of several avrBs $3 / p t h A$ family members severely reduces virulence of 
X. oryzae pv. oryzae on rice (136). Infection of pepper leaves with $X$. campestris pv. vesicatoria expressing avrBs 3 leads to pustule formation as a disease symptom, and transient expression of AvrBs3 protein in tobacco cells leads to host cell hypertrophy (88). Consistent with their potential function as a transcription factor, many host genes are activated when susceptible pepper is infected with $X$. campestris pv. vesicatoria expressing avrBs 3 , including an excess of auxin-inducible genes and expansinlike protein genes.

NB-LRR proteins guard the targets of type III effectors. Type III effector proteins from plant pathogens were initially identified when they were recognized by the products of specific disease resistance genes in specific disease-resistant genotypes of host plant. As outlined above, accumulating evidence indicates that plant disease resistance proteins do not interact directly with their cognate pathogen type III effector in a simple receptor-ligand manner. Instead the plant immune system, via its NB-LRR disease resistance proteins, monitors the action of type III effectors on other plant proteins. These host proteins are most likely type III effector targets that the pathogen manipulates to further its fitness $(30,38)$. In this model, type III effector proteins (and presumably virulence factors from all pathogen classes) could target a finite number of host protein machines to block basal defense, stimulate pathogen nutrient acquisition, or facilitate pathogen dissemination. NB-LRR proteins, in turn, guard these protein machines and recognize their perturbation by pathogen virulence factors. This, in turn, triggers an amplified and accelerated defense response that is nearly always associated with HR at the site of infection.

HopAR1 targets a kinase, PBS1. One genetic consequence of this model is that a host target of type III effector action could be identified as a protein required for activation of a specific NB-LRR protein. The $P$. syringae type III effector HopAR1 (AvrPphB) is a papain-like cysteine protease in the YopT family $(119,138)$ (Table 2). Its target was identified in a mutation screen for genes required for activation of the Arabidopsis RPS5 NB-LRR resistance protein, which recognizes HopAR1. HopAR1 specifically cleaves PBS1 (118), a serine-threonine kinase conserved across plant species (121). If RPS5 is present, cleavage of PBS1 activates a defense response that stops the growth of the infecting pathogen. Following cleavage, PBS1 catalytic residues are still required for RPS5 activation, suggesting that its kinase function is relevant (118). The function of PBS1 in plants that lack RPS5 (and hence are susceptible to bacterial strains expressing HopAR1) is unknown. A pbs1 mutant is not more resistant or susceptible to virulent pathogens than wild type, which means that PBS1 is not a necessary component of basal plant defense (129).

AvrRpt2, AvrRpm1, and AvrB target RIN4, a repressor of basal defense. If type III effector proteins distributed throughout the pathogen population are functionally redundant with respect to the host proteins they target, one would expect to find some that converge onto a common target(s). Three sequence-unrelated $P$. syringae type III effectors, AvrRpm1, AvrB, and AvrRpt2, do converge onto a conserved, plant-specific Arabidopsis protein of unknown function called RIN4. An additional corollary is that any host protein that is independently targeted by pathogen virulence factors might be protected by more than one NB-LRR protein. This is especially true if the mode of action of the type III effectors converging onto that target perturbs its function in different ways. This is also true, since RPM1 and RPS2, two Arabidopsis NB-LRR proteins, are activated following different manipulations of RIN4 by the three type III effector proteins listed above.

RPM1 is associated with the plasma membrane (21). It is activated by either AvrB or AvrRpm1, each of which is myristoylated, and possibly palmitoylated, in the host and subsequently also localized to the plasma 
membrane $(18,52,95)$. RIN4 is also acylated into the plasma membrane (69) and can be coimmunoprecipitated with RPM1 and with either AvrRpm1 or AvrB (85). RIN4 also interacts with both RPM1 and AvrB in yeast two-hybrid experiments (85). When plants are infected with $P$. syringae expressing either AvrB or AvrRpm1, RIN4 becomes hyperphosphorylated (85) (Figure 2a). If RPM1 is present, a disease resistance response is activated. It is still unclear what role RIN4 hyperphosphorylation plays in activation of RPM1.

RPS2 is also associated with the plasma membrane and is activated by AvrRpt 2 . AvrRpt2 is a staphopain-class cysteine protease (12) (Table 2). Like RPM1, RPS2 can

a

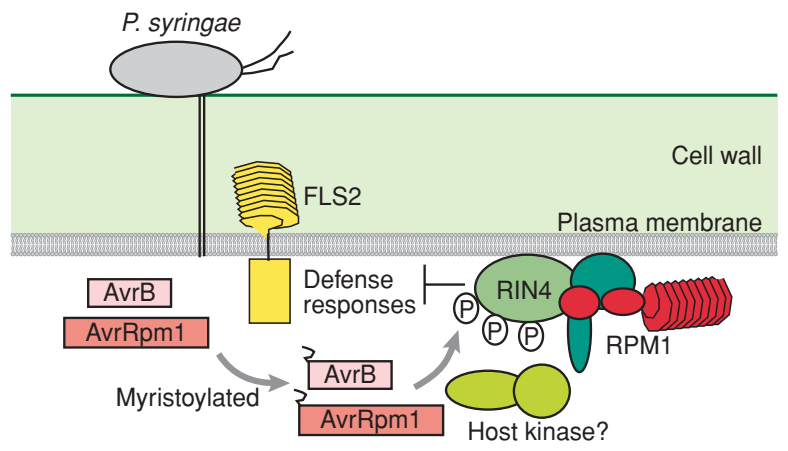

b

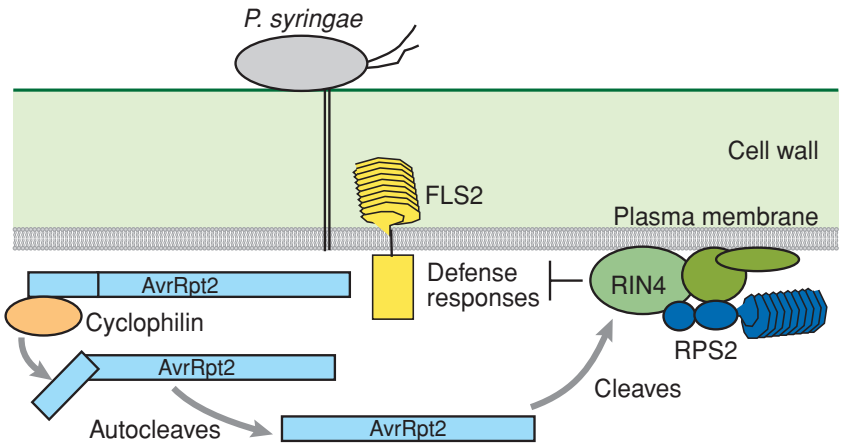

Figure 2

RIN4 is a host target of multiple type III effectors. The activation steps leading to (a) hyperphosphorylation as a result of AvrB or AvrRpm1 action, perhaps in association with other host proteins, and (b) cleavage of RIN4 by AvrRpt2 are illustrated. RIN4 is assumed to be part of a protein complex at the plant membrane that may include resistance proteins, depending on the host genotype. Other potential virulence targets are not included in the illustration. Objects are not drawn to scale. coimmunoprecipitate with RIN4 in plants and interact with it in yeast two-hybrid assays (12, 84). When AvrRpt2 is delivered into host cells, it is activated (92) by a host cyclophilin (32) via autocleavage that removes its N-terminal sequences (Figure $2 \boldsymbol{b}$ ). The activated protein then cleaves RIN4 at two sequences that are actually homologous to its own autocleavage site $(11,39,69)$. Cleavage of RIN4 activates RPS2-mediated disease resistance.

RIN4 is a negative regulator of basal defense responses. The observation that three different type III effectors from diverse $P$. syringae strains target RIN4 suggests it has an important role in plant defense. Kim et al. (71) demonstrated that RIN4 is a negative regulator of basal defense mechanisms stimulated by flg22. Overexpression of RIN4 in plants that lack RPM1 and RPS2 suppresses several markers of basal defense following either infection with a TTSS-defective $P$. syringae or treatment with flg22 peptide. A rin 4 mutant plant responds to flg22 with enhanced callose induction, and the growth of virulent Pto DC3000 is partially inhibited. As a negative regulator of basal defenses, RIN4 is an attractive target for modification by type III effectors. Its hyperphosphorylation by AvrRpm1 or AvrB may stabilize RIN4 in its negative regulatory state. It is not obvious how cleavage of RIN4 by AvrRpt2 can maintain its negative regulatory function, but as an essential part of a protein machine, elimination of RIN4 may prevent subsequent activation of defense components held in that complex. For example, elimination of RIN4 by AvrRpt2 prevents activation of RPM1 by AvrB or AvrRpm1 (84, 110). Alternatively, AvrRpt2 might eliminate RIN4 and other proteins that $(a)$ contain the same cleavage site and $(b)$ are positive regulators of basal defense. Several such candidates exist (see below).

RIN4 is not the virulence target of AvrRpm1 and AvrRpt2. AvrRpm1 and AvrRpt2 are demonstrably virulence factors 
$(29,109)$. However, their ability to enhance pathogen growth is not lost in a rin 4 mutant, the expectation if RIN4 were the only virulence target of either AvrRpm1 or AvrRpt2 (16). Therefore RIN4 is not required for either of these type III effectors to block basal defenses. RIN4 contains two short domains of roughly 25 amino acids that contain the AvrRpt 2 cleavage sites and, in one case, the AvrB binding site, and these are found in a set of additional small Arabidopsis proteins that share no other homology $(31,69)$. It is possible that the primary (virulence) functions of AvrRpm1, AvrB, and AvrRpt2, depend on modification of some, or all, of these proteins. If type III effector proteins generally target multiple host proteins, disease would then be the cumulative result of this multiplicity of manipulations. Disease resistance, though, can be achieved by a particular manipulation activating a single NB-LRR protein. This would be a reasonably efficient way for the plant immune system to achieve "coverage" of the whole set of vulnerable host machines with a limited number of NB-LRR proteins ( $\sim 125$ in the Arabidopsis genome).

AvrPto and HopAB2 (AvrPtoB) target the tomato Pto kinase. Both AvrPto and HopAB2 interact physically with the serinethreonine Pto kinase of tomato (2). Although otherwise structurally different, they both contain a short sequence, GINP, that is required for the interaction of AvrPto with Pto in a yeast two-hybrid assay $(72,133)$. HopAB2 interacts with Pto even if the GINP domain is deleted (2). Both AvrPto and HopAB trigger resistance on tomato plants that express Pto, and this disease resistance response requires the NB-LRR protein Prf (115). According to the guard hypothesis, the NB-LRR protein Prf monitors the interaction of either AvrPto or HopAB2 on Pto to trigger PCD (127). Like RIN4, Pto is not the sole virulence target of AvrPto and HopAB2 because both contribute to virulence on tomato genotypes that lack Pto $(79,117)$. As summarized in Table 1, AvrPto suppresses cell wall- mediated defenses and HopAB2 suppresses PCD. As detailed above, HopAB has a C-terminal domain that suppresses PCD and encodes a U-box class E3 ubiquitin ligase (1, 64). This domain is not necessary for the interaction of HopAB2 with Pto. It is currently unclear how manipulation of Pto by these type III effector proteins activates disease resistance via Prf. There are gain-of-function Pto alleles that are active and Prf dependent in the absence of AvrPto (105). Whereas Pto kinase activity is required for AvrPto-dependent Prf activation, it is dispensable for signaling by the constitutively active Pto allele. These results suggest that Pto signals the activation of Prf through conformational changes rather than phosphorylation of downstream substrates (132).

How does the interaction of AvrPto and HopAB with Pto modulate basal defense? Recently, AvrPto and HopAB2 were identified in a directed test of known type III effectors that could interfere with flg22 induction of early basal defense responses. Expression of FRK1, an Arabidopsis receptor-like kinase, is induced after application of flg22 to plant cells (8). Protoplasts from transgenic Arabidopsis carrying a FRK1 promoter-luciferase fusion were transfected with type III effector genes expressed from a constitutive promoter, and the flg22-dependent induction of luciferase expression was monitored. Of 11 type III effectors tested, only AvrPto and HopAB2 blocked FRK1 expression at a step before the initiation of a MAPK cascade (57). AvrPto and HopAB also blocked basal defense activation by other PAMPS (57). One prediction from these results is that AvrPto and HopAB2 interact with an Arabidopsis Pto ortholog to dampen early activation steps in PAMP recognition.

\section{Distribution of Type III Effectors}

Diverse plant pathogens have unique collections of type III effectors. Plant pathogens with diverse infection strategies, and plantassociated bacteria that can either protect plants from fungal pathogens or live as 
intimately associated symbionts, deploy type III effector proteins, as detailed above. We first surveyed the distribution of type III effector protein families across this variety of plant-associated bacterial species. We created a query database of 98 type III effector protein families using TribeMCL with an e-value of $10^{-8}$ and an inflation value of 1.0 (45). $P$. syringae type III effector protein families were either experimentally confirmed as translocated (27) or identified as type III effector candidates by a variety of computational methods (80) (Table S1, follow the Supplemental Material link from the Annual Reviews home page at http://www.annualreviews.org/).

Each type III effector protein sequence was used as a query for a BLASTp search against the genomes of nine fully sequenced plant pathogen genomes (three pathovars of $P$. syringae, $R$. solanacearum GMI1000, two xanthomonads, and three species of Erwinia), four soil microbes (three strains of $P$. fluorescens and P. putida KT2440), seven mam- mal pathogens (Escherichia coli 0157:H7, two strains each of Yersinia pestis, Salmonella enterica, and Shigella flexneri), and four symbiotic rhizobia (Sinorbizobium meliloti, Rhizobium leguminosarum, Mezorbizobium loti, and Bradyrhizobium japonicum), as well as the symbiotic megaplasmid sequence from Rbizobium spp. NGR234. BLASTp was performed with an e-value of $10^{-10}$. We also included the harpins described above and the ATPase domain of the Yersinia TTSS apparatus, YscN, which acts as a positive control for the TTSS in these strains.

Figure 3 presents the results of this survey, focused on the distribution of the type III effector families present in P. syringae (27, $80)$. The results are clustered by bacterial strain. Here, the strains or species with the most similar type III effector protein collections are closest together (right). The phylogeny of these genomes, based solely on the limited number of type III effector protein families displayed here, does not match the

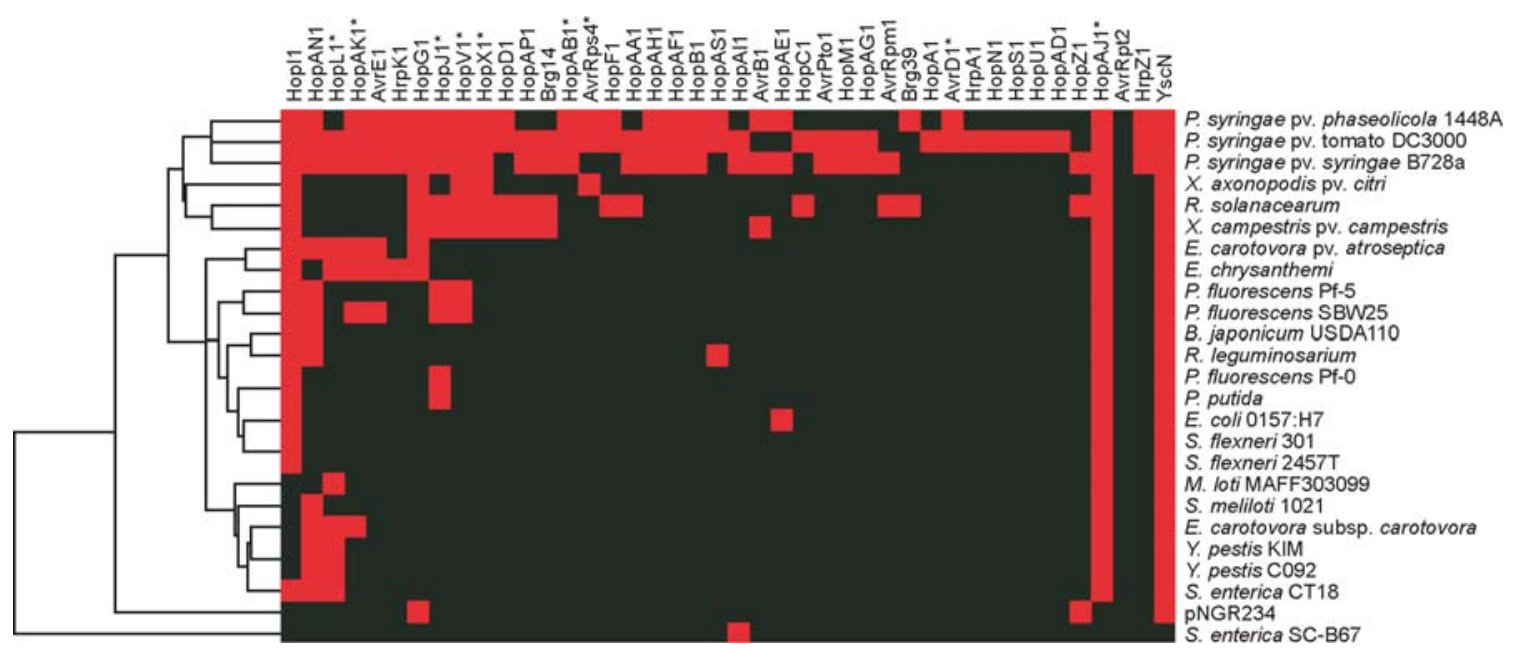

Figure 3

Distribution of effector protein sequences throughout bacterial genomes. BLASTp results are arranged by protein family (see supplemental Figure S1) along the top. The results are clustered by the similarity of type III effector protein collections in each bacterial species surveyed. The clusters were created using Cluster 3.0 (http://bonsai.ims.u-tokyo.ac.jp/ mdehoon/software/cluster/) based on data by Eisen et al. (44), using a value of 1 for "presence" (red) and 0 for "absence" (black), and visualized using JavaTreeView (http://jtreeview.sourceforge.net/). Asterisk indicates that at least one member of this protein family was not able to be translocated as assayed by delivery of a truncated AvrRpt2 fusion (27). 
phylogeny created by MLST analysis using housekeeping protein sequences from AcnA, GltA, GapA, and GyrB protein sequences (46) (data not shown). This strongly suggests that the type III effector suite in any strain is likely to be strongly influenced by horizontal transfer.

It is also evident from Figure 3 that some type III effector proteins co-occur often. For example, members of the HopI1, HopAN1, and HopL1 families are widely codistributed among both plant and animal pathogens as well as in soil microbes. They are found even in strains of $P$. fluorescens that lack TTSS (Pf-0 and Pf-5) (101). Why are these proteins encoded in strains that lack a TTSS? One possibility is that they are ancient genes whose products can, or did, become substrates for the TTSS in some strains. On the other hand, these genes could be evolutionary remnants in genomes that have lost the TTSS-encoding locus. The functions of HopI1 and HopL1 are unknown. HopAN1 family members have a pectate lyase domain $(19,80)$. HopL1 is secreted, and conflicting evidence suggests that it may be a conserved helper protein $(27,35,53)$ (see http://www.pseudomonassyringae.org/).

The suite of type III effectors is unique to each genome analyzed. The type III effector protein suites from the three sequenced strains of $P$. syringae are closely related, and few of these families are found beyond the pseudomonads. To date, 10 type III effector protein families are limited to P. syringae, 4 are only in Xanthomonas spp., and 5 are only in Yersinia (Figure 3; Figure S1, follow the Supplemental Material link from the Annual Reviews home page at http://www.annualreviews.org/). Among the 42 remaining families with more than one member, there is some evidence of assortment between strains, as well as genetic exchange between species (e.g., popC). PopC protein family members are cytoplasmic LRR proteins. Because both plant and animal defense mechanisms involve NB-LRR proteins and other proteins with LRRs (38), PopC proteins may block host defense in diverse hosts.

It is possible that a conserved core set of type III effector proteins is required by all $P$. syringae strains to foster that species' lifestyle on evolutionarily diverse host plants. Their broad distribution among $P$. syringae strains suggests that type III effector proteins have not yet managed to attract the evolutionary attention of the plant's specific immune system. In principle, this could imply that they do not perturb a host protein and are gratuitously delivered to the host. Yet, the wide distribution and significant virulence function for at least some of this class (e.g., the HopM family) argue against this proposition. There is also a set of type III effector proteins that are less well distributed among these three P. syringae strains. These might be candidates for overlapping functions; more sequence comparisons and high-level association studies across strains are required to evaluate this proposal.

Some $P$. syringae type III effector protein families are also represented in the genomes of Ralstonia, Xanthomonas, and Erwinia, but each species also has a collection of type III effector families unique to that species (Figure S1). This pattern suggests that the majority of the type III effector genes evolved after the divergence of plant pathogenic bacteria and perhaps that type III effector genes are rarely exchanged between species by horizontal transmission.

Although our analyses group proteins by overall homology, type III effectors that share enzymatic active sites, such as YopT family members in P. syringae and Yersinia, are not sufficiently related over their total lengths to be identified as homologs in our search. Thus, while this analysis is useful for analyzing distribution of related type III effectors, it is not necessarily able to discriminate between proteins that have similar functions at potentially different cellular targets. This caveat begs the development of high-throughput informatics-based pipelines to annotate possible functional 
domains present in otherwise divergent protein families.

\section{CONCLUSIONS}

Plant pathogens encode larger collections of type III effector proteins than do most animal pathogens, and the collection in each strain analyzed is diverse. We suggest that the balance between the need to have enough type III effectors to ensure virulence on susceptible hosts and the need to avoid recognition by plant disease resistance proteins drives pathogens to diversify their type III effector suites. We have highlighted examples of type III effectors that are required for virulence and individual type III effectors that interfere with diverse aspects of plant basal and specific defense responses. Plant basal defense responses are a complex network that involves the transcriptional reprogramming of over 1000 genes $(93,141)$. We infer that multiple type III effectors are needed to effectively block various branches of this output network. To this end, plant pathogenic bacteria appear to have evolved the capacity to deliver sequence-unrelated type III effector proteins that function in the same, or related, basal defense response pathways. For example, as detailed above, AvrB1, AvrRpm1, and AvrRpt2 all target RIN4 but thus far only rarely cooccur in P. syringae strains. This suggests that convergent evolution is driven by the need to manipulate particular host proteins. In addition, multiple type III effectors in a single strain, Pto DC3000, can block papilla formation (AvrPto, AvrE, and HopM1) or PCD (Table 1).

What evolutionary pressures could drive these assemblages of type III effector genes?
We predict that a collection of type III effectors with overlapping function allows a pathogen population to "lose" one or two effectors, in the face of pressure from the host immune function, without necessarily losing virulence. This loss has been observed in the presence or absence of a particular type III effector virulence gene even within multiple strains of closely related $P$. syringae pathovars (109). Plant breeders adding new specific disease resistance genes to plant varieties often find that virulent "races" of pathogen emerge which have lost, or accrued mutations in, the particular type III effector gene whose product triggered the now-defeated specific disease resistance gene (36).

This pathogen evolution step was recently observed by following the emergence of virulent derivative strains from an avirulent strain of $P$. syringae pv. phaseolicola that encodes the type III effector protein HopAR1 (102). After infection of beans that carry the corresponding disease resistance gene, virulent derivatives that had deleted a large genomic pathogenicity island carrying hopAR1 were recovered. With this kind of strategy, pathogens might run short of virulence factors at some point. New type III effector genes can be acquired by horizontal transmission, reactivation of pseudogenes by excision of a transposable element, or by recombination or transposition-based placement of a type IIIregulated promoter upstream of a "hibernating" type III effector gene. The prevalence of type III effector genes in pathogenicity islands or on plasmids $(7,60)$ and the nonconserved location of type III effectors in different genomes of $P$. syringae (27) indicate that horizontal transmission is active in plant pathogens.

\section{SUMMARY POINTS}

1. Type III effector proteins are essential for the successful life histories of many gramnegative bacteria.

2. Diverse plant disease resistance mechanisms can be blocked by type III effector proteins, but they can also trigger the plant immune system. 
3. Host defenses are complex, involving activation of MAPK pathways, increases in SA signaling, and secretion of toxins, phenolics, and cell wall-strengthening compounds.

4. Type III effectors target specific host proteins, each of which may play a role in some aspect of host defense. As a consequence, multiple type III effectors are needed to effectively block host defense.

5. Structurally diverse type III effectors can have overlapping functions affecting host defense.

6. Because type III effectors can be horizontally transmitted and deletion can lead to increased host range, the collection of type III effectors in each strain can change over time.

7. The collection of type III effectors in any strain is driven by a need to manipulate certain host proteins but also to avoid specific disease resistance mechanisms.

\section{ACKNOWLEDGMENTS}

We thank Darby Brown for Figure 1. We thank William Broughton, Steven Genin, Barbara Kunkel, John Mansfield, Greg Martin, Thorsten Nurnberger, Jen Sheen, Brian Staskawicz, and Maureen Whalen for contribution of manuscripts before publication. We apologize that because of space limitations we could not cover all the papers contributed. Work on type III effector proteins and disease resistance in the Dangl lab is funded by grants from the National Institutes of Health (RO1-GM-0,66,025), the U.S. Department of Energy (DE-FG05-95ER20187), and the National Science Foundation's Arabidopsis 2010 Project (NSF-IOB-05,20,003). The Grant lab's type III effector work is funded by National Science Foundation grants (DEB-0412599 and IBN0416592).

\section{LITERATURE CITED}

1. Abramovitch RB, Janjusevic R, Stebbins CE, Martin GB. 2006. Type III effector AvrPtoB requires intrinsic $\mathrm{E} 3$ ubiquitin ligase activity to suppress plant cell death and immunity. Proc. Natl. Acad. Sci. USA. 103:2851-56

2. Abramovitch RB, Kim YJ, Chen S, Dickman MB, Martin GB. 2003. Pseudomonas type III effector AvrPtoB induces plant disease susceptibility by inhibition of host programmed cell death. EMBO 7. 22:60-69

3. Akeda Y, Galan JE. 2005. Chaperone release and unfolding of substrates in type III secretion. Nature 437:911-15

4. Alfano JR, Charkowski AO, Deng WL, Badel JL, Petnicki-Ocwieja T, et al. 2000. The Pseudomonas syringae Hrp pathogenicity island has a tripartite mosaic structure composed of a cluster of type III secretion genes bounded by exchangeable effector and conserved effector loci that contribute to parasitic fitness and pathogenicity in plants. Proc. Natl. Acad. Sci. USA 97:4856-61

5. Alfano JR, Collmer A. 2004. Type III secretion system effector proteins: double agents in bacterial disease and plant defense. Annu. Rev. Phytopatbol. 42:385-414

6. Arlat M, Gough CL, Barber CE, Boucher C, Daniels MJ. 1991. Xanthomonas campestris contains a cluster of hrp genes related to the larger hrp cluster of Pseudomonas solanacearum. Mol. Plant Microbe. Interact. 4:593-601

\section{Salmonella} chaperone protein SicP directs the type III effector SptP to the TTSS where it is unwound by the ATPase InvC for secretion. 
7. Arnold DL, Jackson RW, Fillingham AJ, Goss SC, Taylor JD, et al. 2001. Highly conserved sequences flank avirulence genes: isolation of novel avirulence genes from Pseudomonas syringae pv. pisi. Microbiology 147:1171-82

8. Asai T, Tena G, Plotnikova J, Willmann MR, Chiu WL, et al. 2002. MAP kinase signaling cascade in Arabidopsis innate immunity. Nature 415:977-83

9. Ausmees N, Kobayashi H, Deakin WJ, Marie C, Krishnan HB, et al. 2004. Characterization of NopP, a type III secreted effector of Rhizobium sp. strain NGR234. F. Bacteriol. 186:4774-80

10. Ausubel FM. 2005. Are innate immune signaling pathways in plants and animals conserved? Nat. Immunol. 6:973-79

11. Axtell MJ, Chisholm ST, Dahlbeck D, Staskawicz BJ. 2003. Genetic and molecular evidence that the Pseudomonas syringae type III effector protein AvrRpt2 is a cysteine protease. Mol. Microbiol. 49:1537-46

12. Axtell MJ, Staskawicz BJ. 2003. Initiation of RPS2-specified disease resistance in Arabidopsis is coupled to the AvrRpt2-directed elimination of RIN4. Cell 112:369-77

13. Bartsev AV, Deakin WJ, Boukli NM, McAlvin CB, Stacey G, et al. 2004. NopL, an effector protein of Rbizobium sp. NGR234, thwarts activation of plant defense reactions. Plant Physiol. 134:871-79

14. Bauer DW, Wei ZM, Beer SV, Collmer A. 1995. Erwinia chrysanthemi harpin Ech: an elicitor of the hypersensitive response that contributes to soft-rot pathogenesis. Mol. Plant Microbe. Interact. 8:484-91

15. Beattie GA, Lindow SE. 1994. Epiphytic fitness of phytopathogenic bacteria: physiological adaptations for growth and survival. Curr. Top. Microbiol. Immunol. 192:1-27

16. Belkhadir Y, Nimchuk Z, Hubert DA, Mackey D, Dangl JL. 2004. Arabidopsis RIN4 negatively regulates disease resistance mediated by RPS2 and RPM1 downstream or independent of the NDR1 signal modulator and is not required for the virulence functions of bacterial type III effectors AvrRpt2 or AvrRpm1. Plant Cell 16:2822-35

17. Bestwick CS, Bennett MH, Mansfield JW. 1995. Hrp mutant of Pseudomonas syringae pv. phaseolicola induces cell wall alterations but not membrane damage leading to the hypersensitive reaction in lettuce. Plant Physiol. 108:503-16

18. Bisgrove SR, Simonich MT, Smith NM, Sattler A, Innes RW. 1994. A disease resistance gene in Arabidopsis with specificity for two different pathogen avirulence genes. Plant Cell 6:927-33

19. Boch J, Joardar V, Gao L, Robertson TL, Lim M, Kunkel BN. 2002. Identification of Pseudomonas syringae pv. tomato genes induced during infection of Arabidopsis thaliana. Mol. Microbiol. 44:73-88

20. Boucher CA, Van Gijsegem F, Barberis PA, Arlat M, Zischek C. 1987. Pseudomonas solanacearum genes controlling both pathogenicity on tomato and hypersensitivity on tobacco are clustered. F. Bacteriol. 169:5626-32

21. Boyes DC, Nam J, Dangl JL. 1998. The Arabidopsis thaliana RPM1 disease resistance gene product is a peripheral plasma membrane protein that is degraded coincident with the hypersensitive response. Proc. Natl. Acad. Sci. USA 95:15849-54

22. BretzJR, Mock NM, Charity JC, Zeyad S, Baker CJ, Hutcheson SW. 2003. A translocated protein tyrosine phosphatase of Pseudomonas syringae pv. tomato DC3000 modulates plant defense response to infection. Mol. Microbiol. 49:389-400

23. Brooks DM, Bender CL, Kunkel BN. 2005. The Pseudomonas syringae phytotoxin coronatine promotes virulence by overcoming salicylic-acid-dependent defences in Arabidopsis thaliana. Mol. Plant. Pathol. 6:629-39 
24. Brown IR, Mansfield JW, Bonas U. 1995. hrp genes in Xanthomonas campestris pv. vesicatoria determine ability to suppress papilla deposition in pepper mesophyll cells. Mol. Plant Microbe Interact. 8:825-36

25. Buell CR, Joardar V, Lindeberg M, Selengut J, Paulsen IT, et al. 2003. The complete genome sequence of the Arabidopsis and tomato pathogen Pseudomonas syringae pv. tomato DC3000. Proc. Natl. Acad. Sci. USA 100:10181-86

26. Buttner D, Bonas U. 2002. Getting across-bacterial type III effector proteins on their way to the plant cell. EMBO F. 21:5313-22

27. Chang JH, Urbach JM, Law TF, Arnold LW, Hu A, et al. 2005. A high-throughput, near-saturating screen for type III effector genes from Pseudomonas syringae. Proc. Natl. Acad. Sci. USA 102:2549-54

28. Charkowski AO, Alfano JR, Preston G, Yuan J, He SY, Collmer A. 1998. The Pseudomonas syringae pv. tomato $\mathrm{HrpW}$ protein has domains similar to harpins and pectate lyases and can elicit the plant hypersensitive response and bind to pectate. F. Bacteriol. 180:5211-17

29. Chen Z, Kloek AP, Boch J, Katagiri F, Kunkel BN. 2000. The Pseudomonas syringae avrRpt2 gene product promotes pathogen virulence from inside plant cells. Mol. Plant Microbe. Interact. 13:1312-21

30. Chisholm ST, Coaker G, Day B, Staskawicz BJ. 2006. Host-microbe interactions: shaping the evolution of the plant immune response. Cell 124:803-14

31. Chisholm ST, Dahlbeck D, Krishnamurthy N, Day B, Sjolander K, Staskawicz BJ. 2005. Molecular characterization of proteolytic cleavage sites of the Pseudomonas syringae effector AvrRpt2. Proc. Natl. Acad. Sci. USA 102:2087-92

32. Coaker G, Falick A, Staskawicz B. 2005. Activation of a phytopathogenic bacterial effector protein by a eukaryotic cyclophilin. Science 308:548-50

33. Cohn JR, Martin GB. 2005. Pseudomonas syringae pv. tomato type III effectors AvrPto and AvrPtoB promote ethylene-dependent cell death in tomato. Plant 7. 44:139-54

34. Collmer A, Badel JL, Charkowski AO, Deng WL, Fouts DE, et al. 2000. Pseudomonas syringae Hrp type III secretion system and effector proteins. Proc. Natl. Acad. Sci. USA 97:8770-77

35. Collmer A, Lindeberg M, Petnicki-Ocwieja T, Schneider DJ, Alfano JR. 2002. Genomic mining type III secretion system effectors in Pseudomonas syringae yields new picks for all TTSS prospectors. Trends Microbiol. 10:462-69

36. Crute IR, Pink D. 1996. Genetics and utilization of pathogen resistance in plants. Plant Cell 8:1747-55

37. Cunnac S, Occhialini A, Barberis P, Boucher C, Genin S. 2004. Inventory and functional analysis of the large Hrp regulon in Ralstonia solanacearum: identification of novel effector proteins translocated to plant host cells through the type III secretion system. Mol. Microbiol. 53:115-28

38. Dangl JL, Jones JD. 2001. Plant pathogens and integrated defense responses to infection. Nature 411:826-33

39. Day B, Dahlbeck D, Huang J, Chisholm ST, Li D, Staskawicz BJ. 2005. Molecular basis for the RIN4 negative regulation of RPS2 disease resistance. Plant Cell 17:1292-305

40. de Torres M, Sanchez P, Fernandez-Delmond I, Grant M. 2003. Expression profiling of the host response to bacterial infection: the transition from basal to induced defense responses in RPM1-mediated resistance. Plant f. 33:665-76

41. DebRoy S, Thilmony R, Kwack YB, Nomura K, He SY. 2004. A family of conserved bacterial effectors inhibits salicylic acid-mediated basal immunity and promotes disease necrosis in plants. Proc. Natl. Acad. Sci. USA 101:9927-32
37. A bioinformatic and functional screen identifies candidate type III effectors in the fully sequenced $R$. solanacearum strain GMI1000. 
57. AvrPto and HopAB2 both interact with Pto of tomato and interfere with early steps in defense-related MAPK signaling in a protoplast expression assay in Arabidopsis.
42. Delaney TP, Friedrich L, Ryals JA. 1995. Arabidopsis signal transduction mutant defective in chemically and biologically induced disease resistance. Proc. Natl. Acad. Sci. USA 92:6602-6

43. Deslandes L, Olivier J, Peeters N, Feng DX, Khounlotham M, et al. 2003. Physical interaction between RRS1-R, a protein conferring resistance to bacterial wilt, and PopP2, a type III effector targeted to the plant nucleus. Proc. Natl. Acad. Sci. USA 100:8024-29

44. Eisen MB, Spellman PT, Brown PO, Botstein D. 1998. Cluster analysis and display of genome-wide expression patterns. Proc. Natl. Acad. Sci. USA 95:14863-68

45. Enright AJ, Van Dongen S, Ouzounis CA. 2002. An efficient algorithm for large-scale detection of protein families. Nucleic Acids Res. 30:1575-84

46. Enright MC, Spratt BG. 1999. Multilocus sequence typing. Trends Microbiol. 7:482-87

47. Espinosa A, Guo M, Tam VC, Fu ZQ, Alfano JR. 2003. The Pseudomonas syringae type III-secreted protein HopPtoD2 possesses protein tyrosine phosphatase activity and suppresses programmed cell death in plants. Mol. Microbiol. 49:377-87

48. Felix G, Boller T. 2003. Molecular sensing of bacteria in plants. The highly conserved RNA-binding motif RNP-1 of bacterial cold shock proteins is recognized as an elicitor signal in tobacco. 7. Biol. Chem. 278:6201-8

49. Genin S, Boucher C. 2004. Lessons learned from the genome analysis of Ralstonia solanacearum. Anпu. Rev. Phytopathol. 42:107-34

50. Glazebrook J. 2005. Contrasting mechanisms of defense against biotrophic and necrotrophic pathogens. Annu. Rev. Phytopathol. 43:205-27

51. Gomez-Gomez L, Boller T. 2002. Flagellin perception: a paradigm for innate immunity. Trends Plant Sci. 7:251-56

52. Grant MR, Godiard L, Straube E, Ashfield T, Lewald J, et al. 1995. Structure of the Arabidopsis RPM1 gene enabling dual specificity disease resistance. Science 269:843-46

53. Guttman DS, Vinatzer BA, Sarkar SF, Ranall MV, Kettler G, Greenberg JT. 2002. A functional screen for the type III (Hrp) secretome of the plant pathogen Pseudomonas syringae. Science 295:1722-26

54. Hardt WD, Chen LM, Schuebel KE, Bustelo XR, Galan JE. 1998. S. typhimurium encodes an activator of Rho GTPases that induces membrane ruffling and nuclear responses in host cells. Cell 93:815-26

55. Hauck P, Thilmony R, He SY. 2003. A Pseudomonas syringae type III effector suppresses cell wall-based extracellular defense in susceptible Arabidopsis plants. Proc. Natl. Acad. Sci. USA 100:8577-82

56. He P, Chintamanani S, Chen Z, Zhu L, Kunkel BN, et al. 2004. Activation of a COI1dependent pathway in Arabidopsis by Pseudomonas syringae type III effectors and coronatine. Plant 7. 37:589-602

57. He P, Shan L, Lin NC, Martin GB, Kemmerling B, et al. 2006. Specific bacterial suppressors of MAMP signaling upstream of MAPKKK in Arabidopsis innate immunity. Cell 125:563-75

58. He SY, Nomura K, Whittam TS. 2004. Type III protein secretion mechanism in mammalian and plant pathogens. Biochim. Biophys. Acta 1694:181-206

59. Hotson A, Chosed R, Shu H, Orth K, Mudgett MB. 2003. Xanthomonas type III effector XopD targets SUMO-conjugated proteins in planta. Mol. Microbiol. 50:377-89

60. Jackson RW, Athanassopoulos E, Tsiamis G, Mansfield JW, Sesma A, et al. 1999. Identification of a pathogenicity island, which contains genes for virulence and avirulence, on a large native plasmid in the bean pathogen Pseudomonas syringae pathovar phaseolicola. Proc. Natl. Acad. Sci. USA 96:10875-80 
61. Jackson RW, Mansfield JW, Arnold DL, Sesma A, Paynter CD, et al. 2000. Excision from tRNA genes of a large chromosomal region, carrying avrPphB, associated with race change in the bean pathogen, Pseudomonas syringae pv. phaseolicola. Mol. Microbiol. 38:186-97

62. Jakobek JL, Smith JA, Lindgren PB. 1993. Suppression of bean defense responses by Pseudomonas syringae. Plant Cell 5:57-63

63. Jamir Y, Guo M, Oh HS, Petnicki-Ocwieja T, Chen S, et al. 2004. Identification of Pseudomonas syringae type III effectors that can suppress programmed cell death in plants and yeast. Plant F. 37:554-65

64. Janjusevic R, Abramovitch RB, Martin GB, Stebbins CE. 2006. A bacterial inhibitor of host programmed cell death defenses is an E3 ubiquitin ligase. Science 311:22226

65. Kang L, Li J, Zhao T, Xiao F, Tang X, et al. 2003. Interplay of the Arabidopsis nonhost resistance gene NHO1 with bacterial virulence. Proc. Natl. Acad. Sci. USA 100:3519-24

66. Kaniga K, Uralil J, Bliska JB, Galan JE. 1996. A secreted protein tyrosine phosphatase with modular effector domains in the bacterial pathogen Salmonella typhimurium. Mol. Microbiol. 21:633-41

67. Kay S, Boch J, Bonas U. 2005. Characterization of AvrBs3-like effectors from a Brassicaceae pathogen reveals virulence and avirulence activities and a protein with a novel repeat architecture. Mol. Plant Microbe. Interact. 18:838-48

68. Keshavarzi M, Soylu S, Brown I, Bonas U, Nicole M, et al. 2004. Basal defenses induced in pepper by lipopolysaccharides are suppressed by Xanthomonas campestris pv. vesicatoria. Mol. Plant Microbe. Interact. 17:805-15

69. Kim HS, Desveaux D, Singer AU, Patel P, Sondek J, Dangl JL. 2005. The Pseudomonas syringae effector AvrRpt2 cleaves its C-terminally acylated target, RIN4, from Arabidopsis membranes to block RPM1 activation. Proc. Natl. Acad. Sci. USA 102:6496-501

70. Kim JF, Ham JH, Bauer DW, Collmer A, Beer SV. 1998. The $h r p C$ and $h r p N$ operons of Erwinia chrysanthemi $\mathrm{EC} 16$ are flanked by $p l c A$ and homologs of hemolysin/adhesin genes and accompanying activator/transporter genes. Mol. Plant Microbe. Interact. 11:563-67

71. Kim MG, da Cunha L, McFall AJ, Belkhadir Y, DebRoy S, et al. 2005. Two Pseudomonas syringae type III effectors inhibit RIN4-regulated basal defense in Arabidopsis. Cell 121:749-59

72. Kim YJ, Lin NC, Martin GB. 2002. Two distinct Pseudomonas effector proteins interact with the Pto kinase and activate plant immunity. Cell 109:589-98

73. Krishnan HB. 2002. NolX of Sinorbizobium fredii USDA257, a type III-secreted protein involved in host range determination, is localized in the infection threads of cowpea (Vigna unguiculata [L.] Walp) and soybean (Glycine max [L.] Merr.) nodules. F. Bacteriol. 184:831-39

74. Kunkel BN, Brooks DM. 2002. Cross talk between signaling pathways in pathogen defense. Curr. Opin. Plant Biol. 5:325-31

75. Kunze G, Zipfel C, Robatzek S, Niehaus K, Boller T, Felix G. 2004. The N terminus of bacterial elongation factor Tu elicits innate immunity in Arabidopsis plants. Plant Cell 16:3496-507

76. Lavie M, Shillington E, Eguiluz C, Grimsley N, Boucher C. 2002. PopP1, a new member of the YopJ/AvrRxv family of type III effector proteins, acts as a host-specificity factor and modulates aggressiveness of Ralstonia solanacearum. Mol. Plant Microbe. Interact. 15:105868
64. The crystal structure of the PCD-inhibiting C-terminal domain of HopAB2 reveals it to be an E3 ligase.

71. RIN4, a target of multiple type III effector proteins, is shown to be a negative regulator of flg22-induced basal defenses in Arabidopsis. 
80. A survey of all type III effectors identified in $P$. syringae strains.
77. Lee J, Klusener B, Tsiamis G, Stevens C, Neyt C, et al. 2001. HrpZ(Psph) from the plant pathogen Pseudomonas syringae pv. phaseolicola binds to lipid bilayers and forms an ion-conducting pore in vitro. Proc. Natl. Acad. Sci. USA 98:289-94

78. Li X, Lin H, Zhang W, Zou Y, Zhang J, et al. 2005. Flagellin induces innate immunity in nonhost interactions that is suppressed by Pseudomonas syringae effectors. Proc. Natl. Acad. Sci. USA 102:12990-95

79. Lin NC, Abramovitch RB, Kim YJ, Martin GB. 2006. Diverse AvrPtoB homologs from several Pseudomonas syringae pathovars elicit Pto-dependent resistance and have similar virulence activities. Appl. Environ. Microbiol. 72:702-12

80. Lindeberg M, Stavrinides J, Chang JH, Alfano JR, Collmer A, et al. 2005. Proposed guidelines for a unified nomenclature and phylogenetic analysis of type III Hop effector proteins in the plant pathogen Pseudomonas syringae. Mol. Plant Microbe. Interact. 18:275-82

81. Lindgren PB, Peet RC, Panopoulos NJ. 1986. Gene cluster of Pseudomonas syringae pv. "phaseolicola" controls pathogenicity of bean plants and hypersensitivity of nonhost plants. 7. Bacteriol. 168:512-22

82. Lopez-Solanilla E, Bronstein PA, Schneider AR, Collmer A. 2004. HopPtoN is a Pseudomonas syringae Hrp (type III secretion system) cysteine protease effector that suppresses pathogen-induced necrosis associated with both compatible and incompatible plant interactions. Mol. Microbiol. 54:353-65

83. Lopez-Solanilla E, Llama-Palacios A, Collmer A, Garcia-Olmedo F, RodriguezPalenzuela P. 2001. Relative effects on virulence of mutations in the sap, pel, and brp loci of Erwinia chrysanthemi. Mol. Plant Microbe. Interact. 14:386-93

84. Mackey D, Belkhadir Y, Alonso JM, Ecker JR, Dangl JL. 2003. Arabidopsis RIN4 is a target of the type III virulence effector AvrRpt2 and modulates RPS2-mediated resistance. Cell 112:379-89

85. Mackey D, Holt BF, Wiig A, Dangl JL. 2002. RIN4 interacts with Pseudomonas syringae type III effector molecules and is required for RPM1-mediated resistance in Arabidopsis. Cell 108:743-54

86. Marie C, Broughton WJ, Deakin WJ. 2001. Rhizobium type III secretion systems: legume charmers or alarmers? Curr. Opin. Plant Biol. 4:336-42

87. Marie C, Deakin WJ, Viprey V, Kopcinska J, Golinowski W, et al. 2003. Characterization of Nops, nodulation outer proteins, secreted via the type III secretion system of NGR234. Mol. Plant Microbe. Interact. 16:743-51

88. Marois E, Van den Ackerveken G, Bonas U. 2002. The Xanthomonas type III effector protein AvrBs3 modulates plant gene expression and induces cell hypertrophy in the susceptible host. Mol. Plant Microbe. Interact. 15:637-46

89. Midland SL, Keen NT, Sims JJ, Midland MM, Stayton MM, et al. 1993. The structures of syringolides 1 and 2: novel C glycosidic elicitors from Pseudomonas syringae pv. tomato. 7. Org. Chem. 58:2940-45

90. Mota LJ, Cornelis GR. 2005. The bacterial injection kit: type III secretion systems. Ann. Med. 37:234-49

91. Mudgett MB. 2005. New insights to the funtion of phytopathogenic bacterial type III effectors in plants. Annu. Rev. Plant Biol. 56:509-31

92. Mudgett MB, Staskawicz BJ. 1999. Characterization of the Pseudomonas syringae pv. tomato AvrRpt2 protein: demonstration of secretion and processing during bacterial pathogenesis. Mol. Microbiol. 32:927-41 
93. Navarro L, Zipfel C, Rowland O, Keller I, Robatzek S, et al. 2004. The transcriptional innate immune response to flg22. Interplay and overlap with Avr gene-dependent defense responses and bacterial pathogenesis. Plant Physiol. 135:1113-28

94. Nawrath C, Heck S, Parinthawong N, Metraux JP. 2002. EDS5, an essential component of salicylic acid-dependent signaling for disease resistance in Arabidopsis, is a member of the MATE transporter family. Plant Cell 14:275-86

95. Nimchuk Z, Marois E, Kjemtrup S, Leister RT, Katagiri F, Dangl JL. 2000. Eukaryotic fatty acylation drives plasma membrane targeting and enhances function of several type III effector proteins from Pseudomonas syringae. Cell 101:353-63

96. Nomura K, Melotto M, He SY. 2005. Suppression of host defense in compatible plantPseudomonas syringae interactions. Curr. Opin. Plant Biol. 8:361-68

97. Nurnberger T, Brunner F, Kemmerling B, Piater L. 2004. Innate immunity in plants and animals: striking similarities and obvious differences. Immunol. Rev. 198:249-66

98. Oh CS, Beer SV. 2005. Molecular genetics of Erwinia amylovora involved in the development of fire blight. FEMS Microbiol. Lett. 253:185-92

99. Orth K, Palmer LE, Bao ZQ, Stewart S, Rudolph AE, et al. 1999. Inhibition of the mitogen-activated protein kinase kinase superfamily by a Yersinia effector. Science 285:1920-23

100. Orth K, Xu Z, Mudgett MB, Bao ZQ, Palmer LE, et al. 2000. Disruption of signaling by Yersinia effector YopJ, a ubiquitin-like protein protease. Science 290:1594-97

101. Paulsen IT, Press CM, Ravel J, Kobayashi DY, Myers GS, et al. 2005. Complete genome sequence of the plant commensal Pseudomonas fluorescens Pf-5. Nat. Biotechnol. 23:873-78

102. Pitman AR, Jackson RW, Mansfield JW, Kaitell V, Thwaites R, Arnold DL. 2005. Exposure to host resistance mechanisms drives evolution of bacterial virulence in plants. Curr. Biol. 15:2230-35

103. Preston GM, Bertrand N, Rainey PB. 2001. Type III secretion in plant growth-promoting Pseudomonas fluorescens SBW25. Mol. Microbiol. 41:999-1014

104. Racape J, Belbahri L, Engelhardt S, Lacombe B, Lee J, et al. 2005. Ca2-dependent lipid binding and membrane integration of PopA, a harpin-like elicitor of the hypersensitive response in tobacco. Mol. Microbiol. 58:1406-20

105. Rathjen JP, Chang JH, Staskawicz BJ, Michelmore RW. 1999. Constitutively active Pto induces a Prf-dependent hypersensitive response in the absence of avrPto. EMBO $\mathcal{F}$. $18: 3232-40$

106. Reuber TL, Ausubel FM. 1996. Isolation of Arabidopsis genes that differentiate between resistance responses mediated by the RPS 2 and RPM1 disease resistance genes. Plant Cell $8: 241-49$

107. Rezzonico F, Binder C, Defago G, Moenne-Loccoz Y. 2005. The type III secretion system of biocontrol Pseudomonas fluorescens $\mathrm{KD}$ targets the phytopathogenic Chromista Pythium ultimum and promotes cucumber protection. Mol. Plant Microbe. Interact. 18:991-1001

108. Rezzonico F, Defago G, Moenne-Loccoz Y. 2004. Comparison of ATPase-encoding type III secretion system $b r c N$ genes in biocontrol fluorescent pseudomonads and in phytopathogenic proteobacteria. Appl. Environ. Microbiol. 70:5119-31

109. Ritter C, Dangl JL. 1995. The avrRpm1 gene of Pseudomonas syringae pv. maculicola is required for virulence on Arabidopsis. Mol. Plant Microbe. Interact. 8:444-53

110. Ritter C, Dangl JL. 1996. Interference between two specific pathogen recognition events mediated by distinct plant disease resistance genes. Plant Cell 8:251-57
102. P. syringae is observed losing the type III effector bopAR1 when exposed to the $R 3$ resistance gene.
107. The TTSS of P. fluorescens $\mathrm{KD}$ is necessary for protection of cucumber against the fungus Pithium ultimum. 
112. A functional screen to identify Xcv proteins translocated into pepper cells identified seven new type III effectors.

120. NopP and NopL TTSS-secreted proteins of the broad-host-range Rbizobium NGR234, contribute to effective nodulation of some hosts, and are phosphorylated in plant extracts.
111. Roden J, Eardley L, Hotson A, Cao Y, Mudgett MB. 2004. Characterization of the Xanthomonas AvrXv4 effector, a SUMO protease translocated into plant cells. Mol. Plant Microbe. Interact. 17:633-43

112. Roden JA, Belt B, Ross JB, Tachibana T, Vargas J, Mudgett MB. 2004. A genetic screen to isolate type III effectors translocated into pepper cells during Xanthomonas infection. Proc. Natl. Acad. Sci. USA 101:16624-29

113. Rohmer L, Kjemtrup S, Marchesini P, Dangl JL. 2003. Nucleotide sequence, functional characterization and evolution of $\mathrm{pFKN}$, a virulence plasmid in Pseudomonas syringae pathovar maculicola. Mol. Microbiol. 47:1545-62

114. Ruckdeschel K, Richter K, Mannel O, Heesemann J. 2001. Arginine-143 of Yersinia enterocolitica YopP crucially determines isotype-related NF-kappaB suppression and apoptosis induction in macrophages. Infect. Immun. 69:7652-62

115. Salmeron JM, Oldroyd GE, Rommens CM, Scofield SR, Kim HS, et al. 1996. Tomato Prf is a member of the leucine-rich repeat class of plant disease resistance genes and lies embedded within the Pto kinase gene cluster. Cell 86:123-33

116. Schechter LM, Roberts KA, Jamir Y, Alfano JR, Collmer A. 2004. Pseudomonas syringae type III secretion system targeting signals and novel effectors studied with a Cya translocation reporter. 7. Bacteriol. 186:543-55

117. Shan L, He P, Zhou JM, Tang X. 2000. A cluster of mutations disrupt the avirulence but not the virulence function of AvrPto. Mol. Plant Microbe. Interact. 13:592-98

118. Shao F, Golstein C, Ade J, Stoutemyer M, Dixon JE, Innes RW. 2003. Cleavage of Arabidopsis PBS1 by a bacterial type III effector. Science 301:1230-33

119. Shao F, Merritt PM, Bao Z, Innes RW, Dixon JE. 2002. A Yersinia effector and a Pseudomonas avirulence protein define a family of cysteine proteases functioning in bacterial pathogenesis. Cell 109:575-88

120. Skorpil P, Saad MM, Boukli NM, Kobayashi H, Ares-Orpel F, et al. 2005. NopP, a phosphorylated effector of Rhizobium sp. strain NGR234, is a major determinant of nodulation of the tropical legumes Flemingia congesta and Tephrosia vogelii. Mol. Microbiol. 57:1304-17

121. Swiderski MR, Innes RW. 2001. The Arabidopsis PBS1 resistance gene encodes a member of a novel protein kinase subfamily. Plant 7. 26:101-12

122. Swords KM, Dahlbeck D, Kearney B, Roy M, Staskawicz BJ. 1996. Spontaneous and induced mutations in a single open reading frame alter both virulence and avirulence in Xanthomonas campestris pv. vesicatoria avrBs2. 7. Bacteriol. 178:4661-69

123. Szurek B, Marois E, Bonas U, Van den Ackerveken G. 2001. Eukaryotic features of the Xanthomonas type III effector AvrBs3: protein domains involved in transcriptional activation and the interaction with nuclear import receptors from pepper. Plant 7. 26:52334

124. Tao Y, Xie Z, Chen W, Glazebrook J, Chang HS, et al. 2003. Quantitative nature of Arabidopsis responses during compatible and incompatible interactions with the bacterial pathogen Pseudomonas syringae. Plant Cell 15:317-30

125. Toth IK, Birch PRJ. 2005. Rotting softly and stealthily. Curr. Opin. Plant Biol. 8:424-29

126. Tsiamis G, Mansfield JW, Hockenhull R, Jackson RW, Sesma A, et al. 2000. Cultivarspecific avirulence and virulence functions assigned to avrPphF in Pseudomonas syringae pv. phaseolicola, the cause of bean halo-blight disease. EMBO F. 19:3204-14

127. van der Biezen EA, Jones JDG. 1998. Plant disease resistance proteins and the "genefor-gene" concept. Trends Biochem. Sci. 23:454-56

128. Viprey V, Del Greco A, Golinowski W, Broughton WJ, Perret X. 1998. Symbiotic implications of type III protein secretion machinery in Rhizobium. Mol. Microbiol. 28:1381-89 
129. Warren RF, Merritt PM, Holub E, Innes RW. 1999. Identification of three putative signal transduction genes involved in $R$ gene-specified disease resistance in Arabidopsis. Genetics 152:401-12

130. White FF, Yang B, Johnson LB. 2000. Prospects for understanding avirulence gene function. Curr. Opin. Plant Biol. 3:291-98

131. Wildermuth MC, Dewdney J, Wu G, Ausubel FM. 2001. Isochorismate synthase is required to synthesize salicylic acid for plant defense. Nature 414:562-65

132. Wu AJ, Andriotis VM, Durrant MC, Rathjen JP. 2004. A patch of surface-exposed residues mediates negative regulation of immune signaling by tomato Pto kinase. Plant Cell 16:2809-21

133. Wulf J, Pascuzzi PE, Fahmy A, Martin GB, Nicholson LK. 2004. The solution structure of type III effector protein AvrPto reveals conformational and dynamic features important for plant pathogenesis. Structure 12:1257-68

134. Yang B, Zhu W, Johnson LB, White FF. 2000. The virulence factor AvrXa7 of Xanthomonas oryzae pv. oryzae is a type III secretion pathway-dependent nuclear-localized double-stranded DNA-binding protein. Proc. Natl. Acad. Sci. USA 97:9807-12

135. Yang KY, Liu Y, Zhang S. 2001. Activation of a mitogen-activated protein kinase pathway is involved in disease resistance in tobacco. Proc. Natl. Acad. Sci. USA 98:741-46

136. Yang S, Perna NT, Cooksey DA, Okinaka Y, Lindow SE, et al. 2004. Genome-wide identification of plant-upregulated genes of Erwinia chrysanthemi 3937 using a GFP-based IVET leaf array. Mol. Plant Microbe. Interact. 17:999-1008

137. Zeidler D, Zahringer U, Gerber I, Dubery I, Hartung T, et al. 2004. Innate immunity in Arabidopsis thaliana: Lipopolysaccharides activate nitric oxide synthase (NOS) and induce defense genes. Proc. Natl. Acad. Sci. USA 101:15811-16

138. Zhu M, Shao F, Innes RW, Dixon JE, Xu Z. 2004. The crystal structure of Pseudomonas avirulence protein AvrPphB: a papain-like fold with a distinct substrate-binding site. Proc. Natl. Acad. Sci. USA 101:302-7

139. Zhu W, Yang B, Chittoor JM, Johnson LB, White FF. 1998. AvrXa10 contains an acidic transcriptional activation domain in the functionally conserved $\mathrm{C}$ terminus. Mol. Plant Microbe. Interact. 11:824-32

140. Zipfel C, Felix G. 2005. Plants and animals: a different taste for microbes? Curr. Opin. Plant Biol. 8:353-60

141. Zipfel C, Kunze G, Chinchilla D, Caniard A, Jones JDG, et al. 2006. Perception of the bacterial PAMP EF-Tu by the Arabidopsis receptor kinase EFR restricts Agrobacteriummediated transformation. Cell 126:749-60

142. Zipfel C, Robatzek S, Navarro L, Oakeley EJ, Jones JD, et al. 2004. Bacterial disease resistance in Arabidopsis through flagellin perception. Nature 428:764-67

RELATED RESOURCES

https://asap.ahabs.wisc.edu/asap/logon.php

http://genome.jgi-psf.org/finished 'microbes/psefl/psefl.download.html

$\mathrm{ftp} / / / \mathrm{ftp}$. sanger.ac.uk/pub/pathogens/pf/

$\mathrm{ftp} / / / \mathrm{ftp}$. sanger.ac.uk/pub/pathogens/rl/ 
Annual Review of Microbiology

Volume 60, 2006

\section{Contents}

Frontispiece

Dale Kaiser .................................................................... xvi

A Microbial Genetic Journey

Dale Kaiser

Radical Enzymes in Anaerobes

Wolfgang Buckel and Bernard T. Golding .....................................27

The Structural and Functional Role of RNA in Icosahedral

Virus Assembly

Anette Schneemann

The Biology of the Cryptococcus neoformans Species Complex

Xiaorong Lin and Foseph Heitman

Arsenic and Selenium in Microbial Metabolism

Fobn F. Stolz, Partha Basu, Foanne M. Santini, and Ronald S. Oremland

Curli Biogenesis and Function

Michelle M. Barnhart and Matthew R. Chapman

Uranium Reduction

fudy D. Wall and Lee R. Krumbolz

Francisella tularensis: Taxonomy, Genetics, and Immunopathogenesis of a Potential Agent of Biowarfare

Molly K. McLendon, Michael A. Apicella, and Lee-Ann H. Allen

Manganese Transport and the Role of Manganese in Virulence

Krisztina M. Papp-Wallace and Michael E. Maguire.

Biochemical Aspects of Coronavirus Replication and Virus-Host Interaction

Luis Enjuanes, Fernando Almazán, Isabel Sola, and Sonia Zuñiga

Environmental Stress and Lesion-Bypass DNA Polymerases

Takebiko Nohmi 
Environmental Biology of the Marine Roseobacter Lineage

Irene Wagner-Döbler and Hanno Biebl

Defining Virulence Genes in the Dimorphic Fungi

Chad A. Rappleye and William E. Goldman

Structure and Function of RNA Replication

Fuan Ortín and Francisco Parra ............................................ 305

Streamlining and Simplification of Microbial Genome Architecture

Michael Lynch

DnaA: Controlling the Initiation of Bacterial DNA Replication and More

fon M. Kaguni

The Bacterial Twin-Arginine Translocation Pathway

Philip A. Lee, Danielle Tullman-Ercek, and George Georgiou

Surface Proteins of Gram-Positive Bacteria and How They Get There

Fune R. Scott and Timothy C. Barnett

Subterfuge and Manipulation: Type III Effector Proteins of

Phytopathogenic Bacteria

Sarab R. Grant, Emily 7. Fisher, Jeff H. Chang, Beth M. Mole,

and feffery L. Dangl

Induction of Competence Regulons as a General Response to Stress in

Gram-Positive Bacteria

Fean-Pierre Claverys, Marc Prudhomme, and Bernard Martin

Origin of Mutations Under Selection: The Adaptive Mutation

Controversy

Fobn R. Roth, Elisabeth Kugelberg, Andrew B. Reams, Eric Kofoid,

and Dan I. Andersson

Virus Counterdefense: Diverse Strategies for Evading the

RNA-Silencing Immunity

Feng Li and Shou-Wei Ding.....

Understanding Microbial Metabolism

Diana M. Downs

Multilocus Sequence Typing of Bacteria

Martin C.F. Maiden 


\section{Supplemental figure and table.}

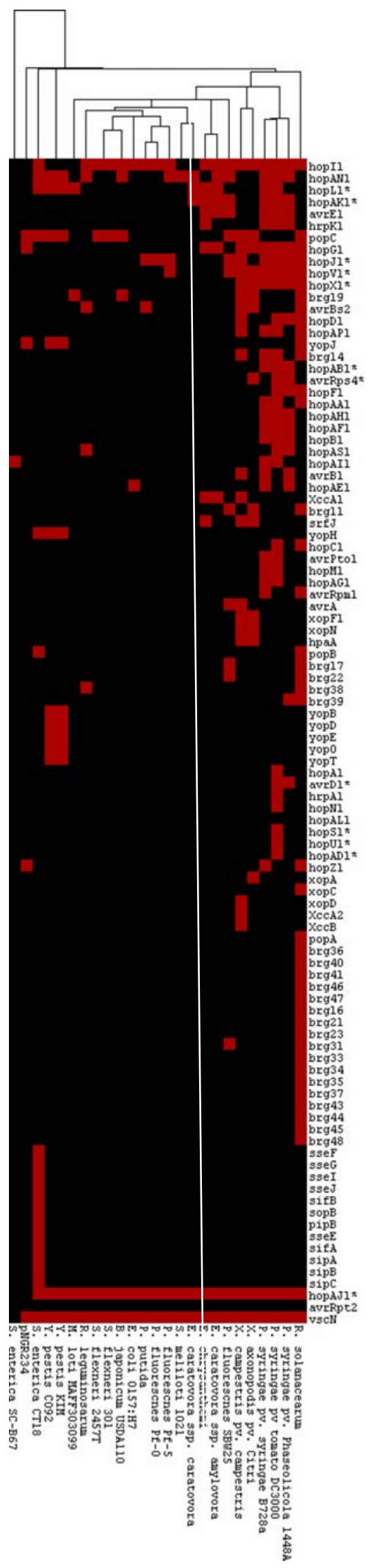

Supplemental Figure 1. Distribution of effector protein sequences throughout bacterial genomes. BLASTp results are arranged by protein family along the top. The results are clustered by the similarity of type III effector protein collections in each bacterial species surveyed. The clusters were created using Cluster 3.0 (http://bonsai.ims.utokyo.ac.ip/ mdehoon/software/cluster/) based on (4) visualized using JavaTreeView. Red indicates presence and black absence.

* indicates that at least one member of this protein family was not able to be translocated as assayed by delivery of a truncated AvrRpt2 fusion (1). 
Supplemental Material: Annu.Rev.Microbiol. 2006. 60:425-49

doi: 10.1146/annurev.micro.60.080805.142251

Subterfuge and Manipulation: Type III Effector Proteins of Phytopathogenic Backteria

Grant, Fisher, Chang, Mole, and Dangl

SUPPLEMENTAL TABLE 1 Type III effector protein families

\begin{tabular}{|c|c|c|c|c|c|c|}
\hline & Name ${ }^{b}$ & Alt. name & Strain & pv. $^{\mathrm{c}}$ & Isolate & Accession \\
\hline $1^{a}$ & Hopl1 & Psyr4326 & P.syringae & syringae & B728a & AAY39356 \\
\hline 1 & Hopl1 & PSPPHA0012 & P.syringae & phaseolicola & $1448 \mathrm{~A}$ & YP_272139 \\
\hline 1 & HopQ1-1 & PSPTO0877 & P.syringae & tomato & DC3000 & NP_790716 \\
\hline 1 & HopQ1-2 & PSPTO4732 & P.syringae & tomato & DC3000 & NP_794471 \\
\hline 1 & Brg20 & RSc0245 & R. solanacearum & & GMI1000 & NP_518366 \\
\hline 1 & XopQ & & X.campestris & vesicatoria & 85-10 & AAV774206 \\
\hline 1 & Hopl1 & HopPmal & P.syringae & maculicola & ES4326 & AF458047 \\
\hline 1 & Hopl1 & PSPPH4366 & P.syringae & phaseolicola & $1448 A$ & YP_276482 \\
\hline 1 & Hopl1 & PSPTO4776 & P.syringae & tomato & DC3000 & NP_794511 \\
\hline 2 & HopAN1 & PSPPH0456 & P.syringae & phaseolicola & $1448 \mathrm{~A}$ & YP_272759 \\
\hline 2 & HopAN1 & PSPT05061 & P.syringae & tomato & DC3000 & NP_794793 \\
\hline 3 & HopL1* & PSPTO2872 & P.syringae & tomato & DC3000 & NP_792673 \\
\hline 3 & HopL1 & Psyr2631 & P.syringae & syringae & $\mathrm{B} 728 \mathrm{a}$ & AAY37670 \\
\hline 4 & HopAK1 & HopPmaH & P.syringae & maculicola & ES4326 & AF458046 \\
\hline 4 & HopAK1* & PSPPH1424 & P.syringae & phaseolicola & $1448 A$ & YP_273680 \\
\hline 4 & HopAK1 & Psyr3839 & P.syringae & syringae & B728a & YP_236907 \\
\hline 4 & HopAK1* & PSPTO4101 & P.syringae & tomato & DC3000 & PSPTO4101 \\
\hline 5 & AvrE1 & & P.syringae & maculicola & ES4326 & AF458405 \\
\hline 5 & AvrE1 & PSPPH1268 & P.syringae & phaseolicola & $1448 A$ & YP_273527 \\
\hline 5 & AvrE1 & Psyr1188 & P.syringae & syringae & $\mathrm{B} 728 \mathrm{a}$ & YP_234280 \\
\hline 5 & AvrE1 & & P.syringae & tomato & РT23 & U16118 \\
\hline 5 & AvrE1 & PSPTO1377 & P.syringae & tomato & DC3000 & NP_791204 \\
\hline 6 & HrpK1 & & P.syringae & phaseolicola & $1302 A$ race 4 & AAA67932 \\
\hline 6 & HrpK1 & PSPPH1295 & P.syringae & phaseolicola & $1448 \mathrm{~A}$ & YP_273554 \\
\hline 6 & HrpK1 & & P.syringae & syringae & 61 & U03855. \\
\hline 6 & HrpK1 & Psyr1218 & P.syringae & syringae & B728a & AAP23132 \\
\hline 6 & HrpK & & P.syringae & maculicola & ES4326 & AAL84241 \\
\hline 6 & HrpK1 & PSPTO1405 & P.syringae & tomato & DC3000 & NP_791232 \\
\hline 7 & PopC & & R. solanacearum & & GMI1000 & NP_522436 \\
\hline 7 & Brg24 & RSp0842 & R. solanacearum & & GMI1000 & NP_522403 \\
\hline 7 & SspH2 & & S. enterica & typhimurium & LT2 & NP_461184 \\
\hline 7 & SspH1 & & S. enterica & typhimurium & & AAD40326 \\
\hline 7 & YopM & & Y.pestis & & $\mathrm{KIM}$ & AAC62580 \\
\hline 8 & HopG1 & PSPPH0767 & P.syringae & phaseolicola & 1448A & YP_273053 \\
\hline 8 & HrpW1 & & P.syringae & maculicola & ES4326 & AF458044 \\
\hline 8 & HopE1 & PSPTO4331 & P.syringae & tomato & DC3000 & NP_794087 \\
\hline 8 & HopG1 & PSPTO4727 & P.syringae & tomato & DC3000 & NP_794468 \\
\hline 8 & PopP1 & RSc0826 & R. solanacearum & & GMI1000 & CAD14570 \\
\hline 8 & Brg6 & RSc2775 & R. solanacearum & & GMI1000 & NP_520896 \\
\hline 8 & Brg12 & RSp0323 & R. solanacearum & & GMI1000 & NP_521884 \\
\hline 9 & HopJ1 & HopPmaJ & P.syringae & maculicola & ES4326 & AF458048 \\
\hline 9 & HopJ1 & PSPPH1068 & P.syringae & phaseolicola & $1448 \mathrm{~A}$ & YP_273338 \\
\hline 9 & HopJ1 & Psyr1017 & P.syringae & syringae & B728a & YP_234111 \\
\hline 9 & HopJ1* & PSPPH0171 & P.syringae & phaseolicola & $1448 A$ & YP_272478 \\
\hline 9 & HopJ1* & PSPTO1179 & P.syringae & tomato & DC3000 & NP_791011 \\
\hline 10 & HopV1* & PSPPH2351 & P.syringae & phaseolicola & $1448 \mathrm{~A}$ & YP_274552 \\
\hline 10 & HopR1 & PSPTO0883 & P.syringae & tomato & DC3000 & NP_790722 \\
\hline 10 & Brg15 & RSp1281 & R. solanacearum & & & NP_522840 \\
\hline
\end{tabular}


Supplemental Material: Annu.Rev.Microbiol. 2006. 60:425-49

doi: 10.1146/annurev.micro.60.080805.142251

Subterfuge and Manipulation: Type III Effector Proteins of Phytopathogenic Backteria

Grant, Fisher, Chang, Mole, and Dangl

\begin{tabular}{|c|c|c|c|c|c|c|}
\hline & Name ${ }^{b}$ & Alt. name & Strain & pv. $^{\mathrm{c}}$ & Isolate & Accession \\
\hline 10 & HopV1 & PSPTO4720 & P.syringae & tomato & DC3000 & NP_794463 \\
\hline 11 & HopX1 & AvrPphE & P. syringae & angulata & & AAP23110 \\
\hline 11 & HopX1 & AvrPphE & P. syringae & delphinii & & AAP23116 \\
\hline 11 & HopX1 & AvrPphE & P. syringae & glycinia & race 4 & AAP23121 \\
\hline 11 & HopX1 & AvrPphE & P. syringae & maculicola & ES4326 & DQ196428 \\
\hline 11 & HopX1 & AvrPphE & P. syringae & maculicola & M6 & AF544992 \\
\hline 11 & HopX1 & AvrPphE & P. syringae & phaseolicola & $1302 \mathrm{~A}$ race 4 & AJ224433 \\
\hline 11 & HopX1* & PSPPH1296 & P. syringae & phaseolicola & $1448 \mathrm{~A}$ & YP_273555 \\
\hline 11 & HopX1 & AvrPphE8 & P. syringae & phaseolicola & B130 & AAP23127 \\
\hline 11 & HopX1 & AvrPphE & P. syringae & phaseolicola & BK378 & AAN85175 \\
\hline 11 & HopX1 & Psyr1220 & P. syringae & syringae & B728a & AAF71495 \\
\hline 11 & HopX1 & HopPsyE2 & P. syringae & syringae & W4N 15 & AAN85190 \\
\hline 11 & HopX1 & AvrPphE & P. syringae & tabaci & ATCC 11528 & AAP23130 \\
\hline 11 & HopX2 & HopPmaB & P. syringae & maculicola & ES4326 & AF458041 \\
\hline 11 & HopX1 & PSPTOA0012 & P. syringae & tomato & DC3000 & AA053315 \\
\hline 11 & Brg9 & RSc3369 & R.solanacearum & & GMI1000 & NP_521488 \\
\hline 11 & AvrXacE1 & AvrXacE1 & X. axonopodis & citrii & str. 306 & $N P \_640642$ \\
\hline 11 & AvrXacE2 & AvrXacE2 & X. axonopodis & citrii & str. 306 & $N P \_643532$ \\
\hline 11 & XccE1 & XccE1 & X. campestris & campestris & ATCC 33913 & NP_636999 \\
\hline 12 & Brg19 & RSc1386 & R. solanacearum & & GMI1000 & NP_519507 \\
\hline 12 & Brg18 & RSp0160 & R. solanacearum & & GMI1000 & NP_521721 \\
\hline 12 & XорP & & X.campestris & vesicatoria & $85-10$ & YP_362967 \\
\hline 13 & AvrBs2 & & X.campestris & campestris & ATCC33913 & NP_635447 \\
\hline 14 & HopD1 & & P.syringae & glycinea & & AJ439731 \\
\hline 14 & HopD1 & AvrPphD & P.syringae & phaseolicola & 1302A race4 & AJ277494 \\
\hline 14 & HopD1 & PSPPHA0010 & P.syringae & phaseolicola & 1448A & YP_272137 \\
\hline 14 & HopD1 & & P.syringae & savastanoi & ITM317 & AJ439730 \\
\hline 14 & HopD1 & PSPTO0876 & P.syringae & tomato & DC3000 & NP_790715 \\
\hline 14 & HopAO1 & PSPTO4722 & P.syringae & tomato & DC3000 & NP_794465 \\
\hline 14 & Brg8 & & R.solanacarum & & GMI1000 & NP_521865 \\
\hline 14 & AvrBs1.1 & & X. campestris & campestris & ATCC 33913 & AAM41387 \\
\hline 14 & ХорВ & & X. campestris & vesicatoria & 85-10 & YP_362312 \\
\hline 15 & HopAP1 & Psyr1890 & P.syringae & syringae & B728a & YP_234972 \\
\hline 15 & HopH1 & & P.syringae & pisi & race 1 & CAC16702 \\
\hline 15 & HopH1 & & P.syringae & syringae & B728a & YP_234971 \\
\hline 15 & HopH1 & PSPTO0588 & P.syringae & tomato & DC3000 & NP_790435 \\
\hline 15 & Brg13 & RSc3290 & R. solanacearum & & GMI1000 & NP_521409 \\
\hline 16 & YopJ & & Y.pestis & & $\mathrm{KIM}$ & NP_857908 \\
\hline 16 & HopZ2 & & P.syringae & pisi & race $4 \mathrm{~A}$ & AJ277495 \\
\hline 16 & Brg7 & RSc0868 & R. solanacearum & & GMI1000 & NP_518989 \\
\hline 16 & XopJ & & X.campestris & vesicatoria & $85-10$ & CAJ23833 \\
\hline 17 & Brg14 & RSp0572 & R. solanacearum & & GMI1000 & NP_522133 \\
\hline 18 & НорАB1 & & P.syringae & glycinea & & AJ439728 \\
\hline 18 & НорАB1 & PSPPHA0127 & P.syringae & phaseolicola & $1448 \mathrm{~A}$ & YP_272234 \\
\hline 18 & HopAB1 & & P.syringae & phaseolicola & 1449B & AAD47203 \\
\hline 18 & НорАВ1 & Psyr4659 & P.syringae & syringae & B728a & AAY39686 \\
\hline 18 & HopAB1 & & P.syringae & savastanoi & ETM317 & CAD29302 \\
\hline 18 & НорАВ3 & HopPmaL & P.syringae & maculicola & ES4326 & AF458391 \\
\hline 18 & НорАВ3 & HolPmaN & P.syringae & maculicola & ES4326 & AF458050 \\
\hline 18 & HopAB3* & PSPPH2294 & P.syringae & phaseolicola & 1448A & AAZ35853 \\
\hline
\end{tabular}


Supplemental Material: Annu.Rev.Microbiol. 2006. 60:425-49

doi: 10.1146/annurev.micro.60.080805.142251

Subterfuge and Manipulation: Type III Effector Proteins of Phytopathogenic Backteria

Grant, Fisher, Chang, Mole, and Dangl

\begin{tabular}{|c|c|c|c|c|c|c|}
\hline & Name $^{b}$ & Alt. name & Strain & pv. $^{\mathrm{c}}$ & Isolate & Accession \\
\hline 18 & HopAB2 & PSPTO3087 & P.syringae & tomato & DC3000 & NP_792881 \\
\hline 19 & AvrRps4 & PSPPHA0087 & P.syringae & phaseolicola & $1448 \mathrm{~A}$ & YP_272198 \\
\hline 19 & AvrRps4 & & P.syringae & pisi & 151 & L43559 \\
\hline 19 & HopK1 & PSPTO0044 & P.syringae & tomato & DC3000 & NP 789904 \\
\hline 19 & HopAQ1* & PSPTO4703 & P.syringae & tomato & DC3000 & NP_794448 \\
\hline 19 & ХopO & & X.campestris & vesicatoria & 85-10 & YP_362786 \\
\hline 20 & HopF1 & AvrPphF & P.syringae & phaseolicola & $1449 A$ & AF231452 \\
\hline 20 & HopF2 & & P.syringae & deliphinii & PDDCC529 & AAP23118 \\
\hline 20 & HopF3 & PSPPH3498 & P.syringae & phaseolicola & 1448A & YP_275650 \\
\hline 20 & HopF2 & PSPTO0502 & P.syringae & tomato & DC3000 & NP_790351 \\
\hline 20 & HopAM1 & AvrPpiB & P.syringae & pisi & $870 a$ & X84843 \\
\hline 20 & HopAM1-1 & PSPTO1022 & P.syringae & tomato & DC3000 & NP_790858 \\
\hline 20 & HopAM1-2 & PSPTOA0005 & P.syringae & tomato & DC3000 & NP_808666 \\
\hline 21 & HopAA1 & HopPtoA1 & P.syringae & maculicola & ES4326 & AF458051 \\
\hline 21 & HopAA1 & Psyr1183 & P.syringae & syringae & B728a & YP_234275 \\
\hline 21 & HорАA1-1 & PSPTO1372 & P.syringae & tomato & DC3000 & NP_791199 \\
\hline 21 & HopAA1-2 & PSPTO4718 & P.syringae & tomato & DC3000 & NP_794461 \\
\hline 22 & HорАH1 & Psyr0779 & P.syringae & syringae & B728a & DAA00388 \\
\hline 22 & HopAH2 & PSPPH3036 & P.syringae & phaseolicola & $1448 \mathrm{~A}$ & YP_275213 \\
\hline 22 & HopAH2 & Psyr3123 & P.syringae & syringae & B728a & YP_236193 \\
\hline 22 & HopAH1 & PSPTO0905 & P.syringae & tomato & DC3000 & NP_790744 \\
\hline 23 & HopAF1 & PSPPH1443 & P.syringae & phaseolicola & $1448 \mathrm{~A}$ & YP_273699 \\
\hline 23 & HopAF1 & Psyr381 & P.syringae & syringae & B728a & AAY38843 \\
\hline 23 & HopAF1 & PSPTO1568 & P.syringae & tomato & DC3000 & NP_79139 \\
\hline 24 & НорB1 & & P.syringae & persicae & 5846 & AAN85146 \\
\hline 24 & HорB2 & & P.syringae & syringae & DH015 & AAN85183 \\
\hline 24 & HopB1 & PSPTO1406 & P.syringae & tomato & DC3000 & NP_791233 \\
\hline 25 & HopAS1 & PSPPH4736 & P.syringae & phaseolicola & $1448 \mathrm{~A}$ & YP_276837 \\
\hline 25 & HopAS1 & PSPTO0474 & P.syringae & tomato & DC3000 & NP_790323 \\
\hline 26 & HopAI1 & PSPTO0906 & P.syringae & tomato & DC3000 & NP_790745 \\
\hline 27 & AvrB1 & AvrB & P.syringae & glycinea & race 4 & M21965 \\
\hline 27 & AvrB2 & AvrC & P.syringae & glycinea & race 4 & M22219 \\
\hline 27 & AvrB2 & & P.syringae & phaseolicola & $1448 \mathrm{~A}$ & YP_272229 \\
\hline 27 & AvrB2 & AvrPphC & P.syringae & phaseolicola & NPS3121 & U10377 \\
\hline 27 & AvrB3 & Psyr1219 & P.syringae & syringae & B728a & AF232005 \\
\hline 27 & AvrB3 & HopPsyC2 & P.syringae & syringae & W4N 15 & AAN85189 \\
\hline 27 & XccC & & X.campestris & campestris & ATCC 33913 & ATCC33913 \\
\hline 28 & HopAE1 & PSPPH4326 & P.syringae & phaseolicola & 1448A & YP_276443 \\
\hline 28 & HopAE1 & Psyr4269 & P.syringae & syringae & B728a & DAA00391 \\
\hline 28 & HopW1-1 & HopPmaA & P.syringae & maculicola & ES4326 & AF458040 \\
\hline 28 & HopW1-2 & & P.syringae & maculicola & ES4326 & AY603980 \\
\hline 29 & XccA1 & & X.campestris & campestris & ATCC33913 & AAM43445 \\
\hline 30 & Brg11 & RSc1815 & R. solanacearum & & GMI1000 & CAD15517 \\
\hline 31 & SrfJ & & S. enterica & typhimurium & LT2 & NP_463287 \\
\hline 32 & YopH & & Y. pestis & & KIM & AAC62606 \\
\hline 33 & HopC1 & AvrPpiC & P.syringae & pisi & 299a race 1 & AJ277496 \\
\hline 33 & HopC1 & PSPTO0589 & P.syringae & tomato & DC3000 & NP_790436 \\
\hline 33 & Brg10 & RSc3212 & R. solanacearum & & GMI1000 & NP_521333 \\
\hline 34 & AvrPto1 & Psyr4919 & P.syringae & syringae & B728a & YP_237984 \\
\hline 34 & AvrPto1 & & P.syringae & tomato & JL1065 & L20425 \\
\hline
\end{tabular}


Supplemental Material: Annu.Rev.Microbiol. 2006. 60:425-49

doi: 10.1146/annurev.micro.60.080805.142251

Subterfuge and Manipulation: Type III Effector Proteins of Phytopathogenic Backteria

Grant, Fisher, Chang, Mole, and Dangl

\begin{tabular}{|c|c|c|c|c|c|c|}
\hline & Name ${ }^{b}$ & Alt. name & Strain & pv. $^{\mathrm{c}}$ & Isolate & Accession \\
\hline 34 & AvrPto1 & PSPTO4001 & P.syringae & tomato & DC3000 & NP_793764 \\
\hline 35 & HopM1 & PSPPH1266 & P.syringae & phaseolicola & 1448A & СР000058 \\
\hline 35 & НорМ1 & Psyr1186 & P.syringae & syringae & B728a & YP_234278 \\
\hline 35 & HopM1 & PSPTO1375 & P.syringae & tomato & DC3000 & NP_791202 \\
\hline 36 & HopAG1 & Psyr0778 & P.syringae & syringae & B728a & DAA00387 \\
\hline 37 & AvrRpm1 & & P.syringae & maculicola & M2 & X67808 \\
\hline 37 & AvrRpm1 & & P.syringae & maculicola & M6 & AF359557 \\
\hline 37 & AvrRpm1 & & P.syringae & pisi & race 7 & AJ222647 \\
\hline 37 & AvrRpm1 & AvrPpiA & P.syringae & pisi & race 2 & X67807 \\
\hline 37 & AvrRpm1 & Psyr0738 & P.syringae & syringae & $\mathrm{B} 728 \mathrm{a}$ & AAY35802 \\
\hline 38 & AvrA & & P.syringae & glycinea & race 6 & M15194 \\
\hline 38 & AvrBs1 & & X.campestris & campestris & АТСС33913 & NP_637464 \\
\hline 39 & XopF1 & & X.campestris & vesicatoria & $85-10$ & CAJ22045 \\
\hline 39 & XopF2 & & X.campestris & vesicatoria & $85-10$ & CAJ24621 \\
\hline 40 & XopN & & X.campestris & vesicatoria & $85-10$ & CAJ24623 \\
\hline 41 & hpaA & & X.campestris & campestris & ATCC33913 & NP_636598 \\
\hline 41 & hpaA & & X.axonopodis & campestris & ATCC 33913 & $N P \_640755$ \\
\hline 42 & PopB & RSp0876 & R. solanacearum & & GMI1000 & NP_522437 \\
\hline 42 & SpiC & STY1727 & S. enterica & typhimurium & LT2 & NC_003198 \\
\hline 43 & Brg17 & RSc1349 & R. solanacearum & & GMI1000 & NP_519470 \\
\hline 44 & Brg22 & RSp0193 & R. solanacearum & & GMI1000 & NP_521754 \\
\hline 45 & Brg38 & RSp1031 & R. solanacearum & & GMI1000 & NP 522592 \\
\hline 46 & Brg39 & RSp0732 & R. solanacearum & & GMI1000 & NP 522293 \\
\hline 47 & YopB & & Y.pestis & & $\mathrm{KIM}$ & NP_857753 \\
\hline 48 & YopD & & Y. pestis & & $\mathrm{KIM}$ & NP_857754 \\
\hline 49 & YopE & & Y.pestis & & $\mathrm{KIM}$ & AAC62587 \\
\hline 50 & YopO & & Y.pestis & & KIM & AAN37536 \\
\hline 51 & Yорт & & Y.pestis & & $\mathrm{KIM}$ & NP_857758 \\
\hline 52 & HopA1 & HopA1 & P.syringae & syringae & 61 & AAF71481 \\
\hline 52 & HopA1 & orf2 & P.syringae & syringae & 226 & AAP23133 \\
\hline 52 & HopA2 & HopA2 & P.syringae & atrofaciens & B143 & AAP23114 \\
\hline 52 & HорА2 & HopPsyA & P.syringae & morsprunorum & & AAP23125 \\
\hline 52 & HopA2 & HopPsyB1 & P.syringae & syringae & 464 & AY147017 \\
\hline 52 & НорА2 & HopPsyB2 & P.syringae & syringae & 5D4198 & AAN85150 \\
\hline 52 & НорА2 & HopPsyB1 & P.syringae & syringae & B-301D & AAN85156 \\
\hline 52 & НорА2 & HopPsyB1 & P.syringae & syringae & B5 & AAN85164 \\
\hline 52 & НорА2 & HopPsyB1 & P.syringae & syringae & B6 & AAN85168 \\
\hline 52 & НорA2 & HopPsyB1 & P.syringae & syringae & BK034 & AAN85172 \\
\hline 52 & HopA2 & HopPsyB1 & P.syringae & syringae & PDDCC 3907 & AAN85186 \\
\hline 52 & НорO1-2 & PSPTO4594 & P.syringae & tomato & DC3000 & NP_794345 \\
\hline 52 & HopA1 & PSPTO5354 & P.syringae & tomato & DC3000 & NP_795084 \\
\hline 52 & HopO1-1 & PSPTOA0018 & P.syringae & tomato & DC3000 & NP_808677 \\
\hline 53 & AvrD1 & AvrD & P.syringae & apii & & AF083919 \\
\hline 53 & AvrD1 & AvrD & P.syringae & glycinea & race 0 & U87225 \\
\hline 53 & AvrD1 & AvrD & P.syringae & glycinea & race 1 & U87226 \\
\hline 53 & AvrD1 & AvrD & P.syringae & glycinea & race 3 & U87227 \\
\hline 53 & AvrD1 & AvrD & P.syringae & glycinea & race 6 & U87227 \\
\hline 53 & AvrD1 & AvrD & P.syringae & lacrymans & & L11335 \\
\hline 53 & AvrD1 & AvrD & P.syringae & lacrymans & & L11334 \\
\hline 53 & AvrD1* & PSPPHA0113 & P.syringae & phaseolicola & 1448A & YP_272223 \\
\hline
\end{tabular}


Supplemental Material: Annu.Rev.Microbiol. 2006. 60:425-49

doi: 10.1146/annurev.micro.60.080805.142251

Subterfuge and Manipulation: Type III Effector Proteins of Phytopathogenic Backteria

Grant, Fisher, Chang, Mole, and Dangl

\begin{tabular}{|c|c|c|c|c|c|c|}
\hline & Name $^{b}$ & Alt. name & Strain & pv. $^{\mathrm{c}}$ & Isolate & Accession \\
\hline 53 & AvrD1 & AvrD & P.syringae & phaseolicola & G50 & U87228 \\
\hline 53 & AvrD1 & AvrD & P.syringae & phaseolicola & NPS3121 & L11336 \\
\hline 53 & AvrD1 & AvrD & P.syringae & tomato & РT23 & J03681 \\
\hline 53 & AvrD1 & AvrD & P.syringae & cilantro & & AF083918 \\
\hline 53 & Норт2 & PSPTO4590 & P.syringae & tomato & DC3000 & NP_794341 \\
\hline 53 & НорТ1-2* & PSPTO4593 & P.syringae & tomato & DC3000 & NP_794344 \\
\hline 53 & HopT1-1* & PSPTOA0019 & P.syringae & tomato & DC3000 & AAO59044 \\
\hline $\begin{array}{l}54 \\
54\end{array}$ & $\begin{array}{l}\text { HrpA1 } \\
\text { HopY1 }\end{array}$ & PSPTO0061 & $\begin{array}{l}\text { P.syringae } \\
\text { P.syringae }\end{array}$ & $\begin{array}{l}\text { maculicola } \\
\text { tomato }\end{array}$ & $\begin{array}{c}\text { M2 } \\
\text { DC3000 }\end{array}$ & $\begin{array}{l}\text { AAQ20005. } \\
\text { NP } 789920\end{array}$ \\
\hline 55 & HopN1 & PSPTO1370 & P.syringae & tomato & DC3000 & NP_791197 \\
\hline 55 & HopAL1 & HopPmaK & P.syringae & maculicola & ES4326 & AF458049 \\
\hline 56 & HopS1* & PSPTO4597 & P.syringae & tomato & DC3000 & NP_794348 \\
\hline 56 & HopS2* & PSPTO4588 & P.syringae & tomato & DC3000 & NP_794339 \\
\hline 57 & HopU1* & PSPTO0501 & P.syringae & tomato & DC3000 & NP_ 790350 \\
\hline 58 & HopAD1* & PSPTO4691 & P.syringae & tomato & DC3000 & NP_794440 \\
\hline 59 & HopZ1 & HopPmaD & P.syringae & maculicola & ES4326 & AF458043 \\
\hline 59 & HopZ1 & & P.syringae & syringae & A2 & AAR02168 \\
\hline 59 & HopZ & Hopz' & P.syringae & syringae & B452 & AY147021 \\
\hline 59 & HopZ3 & Psyr1224 & P.syringae & syringae & $\mathrm{B} 728 \mathrm{a}$ & AAF71492 \\
\hline 60 & XopA & & $X$. campestris & vesicatoria & $85-10$ & CAJ22071 \\
\hline 61 & XopC & & $X$. campestris & vesicatoria & $85-10$ & CAJ24112 \\
\hline 62 & XopD & & X.campestris & vesicatoria & $85-10$ & CAJ22068 \\
\hline 63 & XccA2 & & $X$.campestris & campestris & ATCC33913 & AAM41674 \\
\hline 64 & XccB & AvrXccB & X.campestris & campestris & ATCC33913 & AAM42989 \\
\hline 65 & PopA & RSp0877 & R. solanacearum & & GMI1000 & NP_522438 \\
\hline 65 & Brg28 & RSc1356 & R. solanacearum & & GMI1000 & NP_519477 \\
\hline 65 & Brg29 & RSc1357 & R. solanacearum & & GMI1000 & NP_519478 \\
\hline 65 & Brg26 & RSc1800 & R. solanacearum & & GMI1000 & NP_519921 \\
\hline 65 & $\operatorname{Brg} 27$ & RSc1801 & R. solanacearum & & GMI1000 & NP_519922 \\
\hline 65 & Brg25 & RSp0672 & R. solanacearum & & GMI1000 & NP_522233 \\
\hline 66 & $\mathrm{Brg} 36$ & RSc2359 & R. solanacearum & & GMI1000 & NP_ 520480 \\
\hline 67 & Brg40 & RSc3272 & R. solanacearum & & GMI1000 & NP_521391 \\
\hline 68 & Brg41 & RSc1475 & R. solanacearum & & GMI1000 & NP_519596 \\
\hline 69 & Brg46 & RSc0608 & R. solanacearum & & GMI1000 & NP_518729 \\
\hline 70 & Brg47 & RSc3174 & R. solanacearum & & GMI1000 & NP_521295 \\
\hline 71 & Brg16 & RSp0213 & R. solanacearum & & GMI1000 & NP_518334 \\
\hline 72 & Brg21 & RSp0218 & R. solanacearum & & GMI1000 & NP_518339 \\
\hline 73 & Brg23 & RSp0257 & R. solanacearum & & GMI1000 & NP_521818 \\
\hline 74 & Brg31 & RSp0099 & R. solanacearum & & GMI1000 & NP_521660 \\
\hline 74 & Brg32 & RSp0847 & R. solanacearum & & GMI1000 & NP_522408 \\
\hline 74 & Brg30 & RSp1024 & R. solanacearum & & GMI1000 & NP_522585 \\
\hline 75 & Brg33 & RSp0845 & R. solanacearum & & GMI1000 & NP_522406 \\
\hline 76 & Brg34 & RSp0879 & R. solanacearum & & GMI1000 & NP_522440 \\
\hline 77 & Brg35 & RSp0885 & R. solanacearum & & GMI1000 & NP 522446 \\
\hline 78 & Brg37 & RSp1022 & R. solanacearum & & GMI1000 & NP 522583 \\
\hline 79 & Brg43 & RSp1384 & R. solanacearum & & GMI1000 & NP 522943 \\
\hline 80 & $\mathrm{Brg} 44$ & RSp1130 & R. solanacearum & & GMI1000 & NP 522691 \\
\hline 81 & $\mathrm{Brg} 45$ & RSp1460 & R. solanacearum & & GMI1000 & NP 523019 \\
\hline 82 & Brg48 & RSp1388 & R. solanacearum & & GMI1000 & NP 522947 \\
\hline 83 & SseF & & S. enterica & typhimurium & LT2 & NP 460369 \\
\hline
\end{tabular}


Supplemental Material: Annu.Rev.Microbiol. 2006. 60:425-49

doi: 10.1146/annurev.micro.60.080805.142251

Subterfuge and Manipulation: Type III Effector Proteins of Phytopathogenic Backteria

Grant, Fisher, Chang, Mole, and Dangl

\begin{tabular}{|c|c|c|c|c|c|c|}
\hline & Name $^{b}$ & Alt. name & Strain & pv. $^{\mathrm{c}}$ & Isolate & Accession \\
\hline 84 & SseG & & S. enterica & typhimurium & LT2 & NP 460370 \\
\hline 85 & Ssel & & S. enterica & typhimurium & LT2 & AAL19985 \\
\hline 86 & SseJ & & S. enterica & typhimurium & LT2 & AE008772 \\
\hline 87 & SifB & & S. enterica & typhimurium & LT2 & NC_003197 \\
\hline 88 & SopB & & S. enterica & typhimurium & LT2 & NC_003197 \\
\hline 89 & PipB & & S. enterica & typhimurium & LT2 & NC_003197 \\
\hline 90 & SseE & & S. enterica & typhimurium & LT2 & NP_460367 \\
\hline 91 & SifA & & S. enterica & typhimurium & LT2 & AAL20153 \\
\hline 92 & SipA & STY3005 & S. enterica & typhimurium & CT18 & NP_457276 \\
\hline 93 & SipB & STY3008 & S. enterica & typhimurium & CT18 & NP_457279 \\
\hline 94 & SipC & STY3007 & S. enterica & typhimurium & CT18 & NP_457278 \\
\hline 95 & HopAJ1 & HopPmaG & P. syringae & maculicola & ES4326 & AF458045 \\
\hline 95 & HopAJ1* & PSPPH_0763 & P.syringae & phaseolicola & $1448 A$ & AAZ34315.1 \\
\hline 95 & HopAJ2 & PSPPH_4398 & P.syringae & phaseolicola & $1448 \mathrm{~A}$ & AAZ34636.1 \\
\hline 95 & HopAJ2 & Psyr_4357 & P. syringae & syringae & B728a & AAY39387.1 \\
\hline 95 & HopAJ1* & PSPTO0852 & P.syringae & tomato & DC3000 & NP 790692.1 \\
\hline 95 & HopAJ2 & PSPTO4817 & P.syringae & tomato & DC3000 & NP 794551.1 \\
\hline 96 & AvrRpt2 & & P.syringae & tomato & JL1065 & L11355 \\
\hline 97 & HopAR1 & AvrPphB & P.syringae & phaseolicola & race3 & M86401 \\
\hline 98 & HrpZ1 & & P.syringae & carambola & HL1 & AY372185 \\
\hline 98 & HrpZ1 & & P.syringae & apata & & AF092879 \\
\hline 98 & HrpZ1 & & P.syringae & glycinia & race 4 & L41862 \\
\hline 98 & HrpZ1 & & P.syringae & maculicola & M2 & AY325899 \\
\hline 98 & HrpZ1 & & P.syringae & phaseolicola & 1302A race4 & AF268940 \\
\hline 98 & HrpZ1 & PSPPH_1273 & P.syringae & phaseolicola & $1448 \mathrm{~A}$ & AAZ34500.1 \\
\hline 98 & HrpZ1 & & P.syringae & pisi & race 1 & AB018082 \\
\hline 98 & HrpZ1 & & P.syringae & pisi & race 2 & AB018083 \\
\hline 98 & HrpZ1 & & P.syringae & pisi & race 3 & AB018084 \\
\hline 98 & HrpZ1 & & P.syringae & pisi & race 4 & AB018085 \\
\hline 98 & HrpZ1 & & P.syringae & syringae & 61 & L14775 \\
\hline 98 & HrpZ1 & Psyr_1193 & P.syringae & syringae & $\mathrm{B} 728 \mathrm{a}$ & AAY36247.1 \\
\hline 98 & HrpZ1 & & P.syringae & syringae & LOB201 & AB102727 \\
\hline 98 & HrpZ1 & & P.syringae & syringae & NV & AF031667 \\
\hline 98 & HrpZ1 & & P.syringae & tabaci & 6605 & AB049570 \\
\hline 98 & HrpZ1 & PSPTO1382 & P.syringae & tomato & DC3000 & NP_791209 \\
\hline 99 & YscN & & Y. pestis & & KIM & NP_668159 \\
\hline
\end{tabular}

\footnotetext{
Supplemental Table 1 Notes:

${ }^{a}$ Bold font indicates proteins families represented in Figure 3 of the main text.

${ }^{b}$ Proteins marked (*) are not translocated using full length fusions to truncated AvrRpt2 as an assay (1). Note that other members of some of these families are either not tested, or have been demonstrated to be translocated.

${ }^{\mathrm{c}}$ Pathovar
} 
Supplemental Table 1. Analysis: Proteins were identified as type III effectors based on other studies. $P$. syringae were either experimentally confirmed as translocated (1) or identified as type III effector candidates by a variety of computational methods (5). R. solanacearum GMI1000 proteins were found based on their hrp-dependent transcriptional regulation (2). 41 of these are predicted type III effectors and were included along with known $R$. solanacearum type III effector protein PopC. Other sources for type III effector protein sequences were: Salmonella enterica (8); Yersinia pestis (7); Xanthomonas spp. (6) and (3).

\section{LITERATURE CITED}

1. Chang JH, Urbach JM, Law TF, Arnold LW, Hu A, et al. 2005. A highthroughput, near-saturating screen for type III effector genes from Pseudomonas syringae. Proc Natl Acad Sci U S A 102: 2549-54

2. Cunnac S, Occhialini A, Barberis P, Boucher C, Genin S. 2004. Inventory and functional analysis of the large Hrp regulon in Ralstonia solanacearum: identification of novel effector proteins translocated to plant host cells through the type III secretion system. Mol Microbiol 53: 115-28

3. da Silva AC, Ferro JA, Reinach FC, Farah CS, Furlan LR, et al. 2002. Comparison of the genomes of two Xanthomonas pathogens with differing host specificities. Nature 417: 459-63

4. Eisen MB, Spellman PT, Brown PO, Botstein D. 1998. Cluster analysis and display of genome-wide expression patterns. Proc Natl Acad Sci U S A 95: 14863-8

5. Lindeberg M, Stavrinides J, Chang JH, Alfano JR, Collmer A, et al. 2005. Proposed guidelines for a unified nomenclature and phylogenetic analysis of type III Hop effector proteins in the plant pathogen Pseudomonas syringae. Mol Plant Microbe Interact 18: 275-82

6. Roden JA, Belt B, Ross JB, Tachibana T, Vargas J, Mudgett MB. 2004. A genetic screen to isolate type III effectors translocated into pepper cells during Xanthomonas infection. Proc Natl Acad Sci U S A 101: 16624-9

7. Viboud GI, Bliska JB. 2005. Yersinia outer proteins: role in modulation of host cell signaling responses and pathogenesis. Annu Rev Microbiol 59: 69-89

8. Waterman SR, Holden DW. 2003. Functions and effectors of the Salmonella pathogenicity island 2 type III secretion system. Cell Microbiol 5: 501-11 


\section{Supplemental figure and table.}

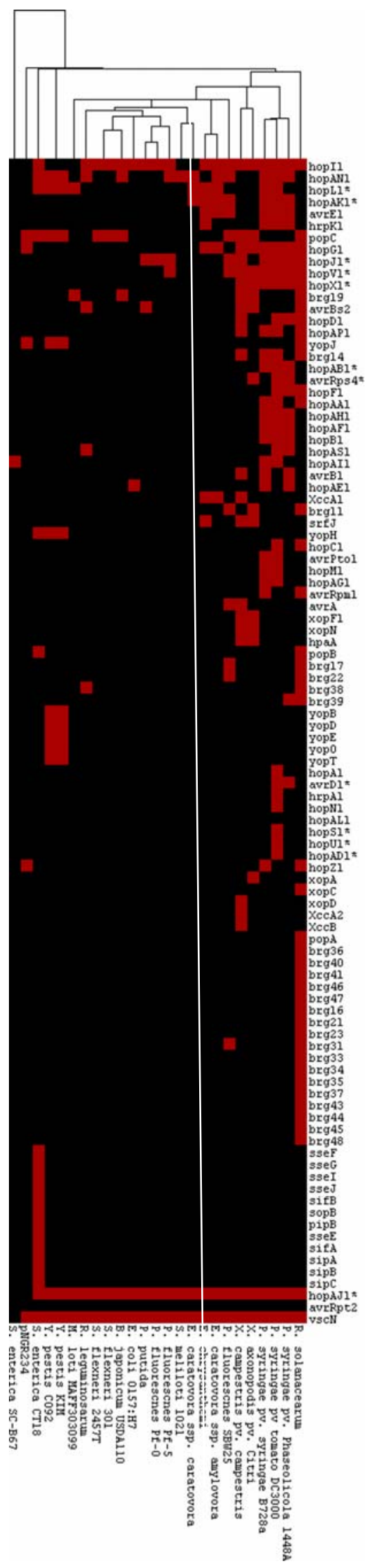

Supplemental Figure 1. Distribution of effector protein sequences throughout bacterial genomes. BLASTp results are arranged by protein family along the top. The results are clustered by the similarity of type III effector protein collections in each bacterial species surveyed. The clusters were created using Cluster 3.0 (http://bonsai.ims.utokyo.ac.ip/ mdehoon/software/cluster/) based on (4) visualized using JavaTreeView. Red indicates presence and black absence.

* indicates that at least one member of this protein family was not able to be translocated as assayed by delivery of a truncated AvrRpt2 fusion (1). 
Supplemental Material: Annu.Rev.Microbiol. 2006. 60:425-49

doi: 10.1146/annurev.micro.60.080805.142251

Subterfuge and Manipulation: Type III Effector Proteins of Phytopathogenic Backteria

Grant, Fisher, Chang, Mole, and Dangl

SUPPLEMENTAL TABLE 1 Type III effector protein families

\begin{tabular}{|c|c|c|c|c|c|c|}
\hline & Name ${ }^{b}$ & Alt. name & Strain & pv. $^{\mathrm{c}}$ & Isolate & Accession \\
\hline $1^{a}$ & Hopl1 & Psyr4326 & P.syringae & syringae & B728a & AAY39356 \\
\hline 1 & Hopl1 & PSPPHA0012 & P.syringae & phaseolicola & $1448 \mathrm{~A}$ & YP_272139 \\
\hline 1 & HopQ1-1 & PSPTO0877 & P.syringae & tomato & DC3000 & NP_790716 \\
\hline 1 & HopQ1-2 & PSPTO4732 & P.syringae & tomato & DC3000 & NP_794471 \\
\hline 1 & Brg20 & RSc0245 & R. solanacearum & & GMI1000 & NP_518366 \\
\hline 1 & XopQ & & X.campestris & vesicatoria & 85-10 & AAV774206 \\
\hline 1 & Hopl1 & HopPmal & P.syringae & maculicola & ES4326 & AF458047 \\
\hline 1 & Hopl1 & PSPPH4366 & P.syringae & phaseolicola & $1448 A$ & YP_276482 \\
\hline 1 & Hopl1 & PSPTO4776 & P.syringae & tomato & DC3000 & NP_794511 \\
\hline 2 & HopAN1 & PSPPH0456 & P.syringae & phaseolicola & $1448 \mathrm{~A}$ & YP_272759 \\
\hline 2 & HopAN1 & PSPT05061 & P.syringae & tomato & DC3000 & NP_794793 \\
\hline 3 & HopL1* & PSPTO2872 & P.syringae & tomato & DC3000 & NP_792673 \\
\hline 3 & HopL1 & Psyr2631 & P.syringae & syringae & $\mathrm{B} 728 \mathrm{a}$ & AAY37670 \\
\hline 4 & HopAK1 & HopPmaH & P.syringae & maculicola & ES4326 & AF458046 \\
\hline 4 & HopAK1* & PSPPH1424 & P.syringae & phaseolicola & $1448 A$ & YP_273680 \\
\hline 4 & HopAK1 & Psyr3839 & P.syringae & syringae & B728a & YP_236907 \\
\hline 4 & HopAK1* & PSPTO4101 & P.syringae & tomato & DC3000 & PSPTO4101 \\
\hline 5 & AvrE1 & & P.syringae & maculicola & ES4326 & AF458405 \\
\hline 5 & AvrE1 & PSPPH1268 & P.syringae & phaseolicola & $1448 A$ & YP_273527 \\
\hline 5 & AvrE1 & Psyr1188 & P.syringae & syringae & $\mathrm{B} 728 \mathrm{a}$ & YP_234280 \\
\hline 5 & AvrE1 & & P.syringae & tomato & РT23 & U16118 \\
\hline 5 & AvrE1 & PSPTO1377 & P.syringae & tomato & DC3000 & NP_791204 \\
\hline 6 & HrpK1 & & P.syringae & phaseolicola & $1302 A$ race 4 & AAA67932 \\
\hline 6 & HrpK1 & PSPPH1295 & P.syringae & phaseolicola & $1448 \mathrm{~A}$ & YP_273554 \\
\hline 6 & HrpK1 & & P.syringae & syringae & 61 & U03855. \\
\hline 6 & HrpK1 & Psyr1218 & P.syringae & syringae & B728a & AAP23132 \\
\hline 6 & HrpK & & P.syringae & maculicola & ES4326 & AAL84241 \\
\hline 6 & HrpK1 & PSPTO1405 & P.syringae & tomato & DC3000 & NP_791232 \\
\hline 7 & PopC & & R. solanacearum & & GMI1000 & NP_522436 \\
\hline 7 & Brg24 & RSp0842 & R. solanacearum & & GMI1000 & NP_522403 \\
\hline 7 & SspH2 & & S. enterica & typhimurium & LT2 & NP_461184 \\
\hline 7 & SspH1 & & S. enterica & typhimurium & & AAD40326 \\
\hline 7 & YopM & & Y.pestis & & $\mathrm{KIM}$ & AAC62580 \\
\hline 8 & HopG1 & PSPPH0767 & P.syringae & phaseolicola & 1448A & YP_273053 \\
\hline 8 & HrpW1 & & P.syringae & maculicola & ES4326 & AF458044 \\
\hline 8 & HopE1 & PSPTO4331 & P.syringae & tomato & DC3000 & NP_794087 \\
\hline 8 & HopG1 & PSPTO4727 & P.syringae & tomato & DC3000 & NP_794468 \\
\hline 8 & PopP1 & RSc0826 & R. solanacearum & & GMI1000 & CAD14570 \\
\hline 8 & Brg6 & RSc2775 & R. solanacearum & & GMI1000 & NP_520896 \\
\hline 8 & Brg12 & RSp0323 & R. solanacearum & & GMI1000 & NP_521884 \\
\hline 9 & HopJ1 & HopPmaJ & P.syringae & maculicola & ES4326 & AF458048 \\
\hline 9 & HopJ1 & PSPPH1068 & P.syringae & phaseolicola & $1448 \mathrm{~A}$ & YP_273338 \\
\hline 9 & HopJ1 & Psyr1017 & P.syringae & syringae & B728a & YP_234111 \\
\hline 9 & HopJ1* & PSPPH0171 & P.syringae & phaseolicola & $1448 A$ & YP_272478 \\
\hline 9 & HopJ1* & PSPTO1179 & P.syringae & tomato & DC3000 & NP_791011 \\
\hline 10 & HopV1* & PSPPH2351 & P.syringae & phaseolicola & $1448 \mathrm{~A}$ & YP_274552 \\
\hline 10 & HopR1 & PSPTO0883 & P.syringae & tomato & DC3000 & NP_790722 \\
\hline 10 & Brg15 & RSp1281 & R. solanacearum & & & NP_522840 \\
\hline
\end{tabular}


Supplemental Material: Annu.Rev.Microbiol. 2006. 60:425-49

doi: 10.1146/annurev.micro.60.080805.142251

Subterfuge and Manipulation: Type III Effector Proteins of Phytopathogenic Backteria

Grant, Fisher, Chang, Mole, and Dangl

\begin{tabular}{|c|c|c|c|c|c|c|}
\hline & Name ${ }^{b}$ & Alt. name & Strain & pv. $^{\mathrm{c}}$ & Isolate & Accession \\
\hline 10 & HopV1 & PSPTO4720 & P.syringae & tomato & DC3000 & NP_794463 \\
\hline 11 & HopX1 & AvrPphE & P. syringae & angulata & & AAP23110 \\
\hline 11 & HopX1 & AvrPphE & P. syringae & delphinii & & AAP23116 \\
\hline 11 & HopX1 & AvrPphE & P. syringae & glycinia & race 4 & AAP23121 \\
\hline 11 & HopX1 & AvrPphE & P. syringae & maculicola & ES4326 & DQ196428 \\
\hline 11 & HopX1 & AvrPphE & P. syringae & maculicola & M6 & AF544992 \\
\hline 11 & HopX1 & AvrPphE & P. syringae & phaseolicola & $1302 \mathrm{~A}$ race 4 & AJ224433 \\
\hline 11 & HopX1* & PSPPH1296 & P. syringae & phaseolicola & $1448 \mathrm{~A}$ & YP_273555 \\
\hline 11 & HopX1 & AvrPphE8 & P. syringae & phaseolicola & B130 & AAP23127 \\
\hline 11 & HopX1 & AvrPphE & P. syringae & phaseolicola & BK378 & AAN85175 \\
\hline 11 & HopX1 & Psyr1220 & P. syringae & syringae & B728a & AAF71495 \\
\hline 11 & HopX1 & HopPsyE2 & P. syringae & syringae & W4N 15 & AAN85190 \\
\hline 11 & HopX1 & AvrPphE & P. syringae & tabaci & ATCC 11528 & AAP23130 \\
\hline 11 & HopX2 & HopPmaB & P. syringae & maculicola & ES4326 & AF458041 \\
\hline 11 & HopX1 & PSPTOA0012 & P. syringae & tomato & DC3000 & AA053315 \\
\hline 11 & Brg9 & RSc3369 & R.solanacearum & & GMI1000 & NP_521488 \\
\hline 11 & AvrXacE1 & AvrXacE1 & X. axonopodis & citrii & str. 306 & $N P \_640642$ \\
\hline 11 & AvrXacE2 & AvrXacE2 & X. axonopodis & citrii & str. 306 & $N P \_643532$ \\
\hline 11 & XccE1 & XccE1 & X. campestris & campestris & ATCC 33913 & NP_636999 \\
\hline 12 & Brg19 & RSc1386 & R. solanacearum & & GMI1000 & NP_519507 \\
\hline 12 & Brg18 & RSp0160 & R. solanacearum & & GMI1000 & NP_521721 \\
\hline 12 & XорP & & X.campestris & vesicatoria & $85-10$ & YP_362967 \\
\hline 13 & AvrBs2 & & X.campestris & campestris & ATCC33913 & NP_635447 \\
\hline 14 & HopD1 & & P.syringae & glycinea & & AJ439731 \\
\hline 14 & HopD1 & AvrPphD & P.syringae & phaseolicola & 1302A race4 & AJ277494 \\
\hline 14 & HopD1 & PSPPHA0010 & P.syringae & phaseolicola & 1448A & YP_272137 \\
\hline 14 & HopD1 & & P.syringae & savastanoi & ITM317 & AJ439730 \\
\hline 14 & HopD1 & PSPTO0876 & P.syringae & tomato & DC3000 & NP_790715 \\
\hline 14 & HopAO1 & PSPTO4722 & P.syringae & tomato & DC3000 & NP_794465 \\
\hline 14 & Brg8 & & R.solanacarum & & GMI1000 & NP_521865 \\
\hline 14 & AvrBs1.1 & & X. campestris & campestris & ATCC 33913 & AAM41387 \\
\hline 14 & ХорВ & & X. campestris & vesicatoria & 85-10 & YP_362312 \\
\hline 15 & HopAP1 & Psyr1890 & P.syringae & syringae & B728a & YP_234972 \\
\hline 15 & HopH1 & & P.syringae & pisi & race 1 & CAC16702 \\
\hline 15 & HopH1 & & P.syringae & syringae & B728a & YP_234971 \\
\hline 15 & HopH1 & PSPTO0588 & P.syringae & tomato & DC3000 & NP_790435 \\
\hline 15 & Brg13 & RSc3290 & R. solanacearum & & GMI1000 & NP_521409 \\
\hline 16 & YopJ & & Y.pestis & & $\mathrm{KIM}$ & NP_857908 \\
\hline 16 & HopZ2 & & P.syringae & pisi & race $4 \mathrm{~A}$ & AJ277495 \\
\hline 16 & Brg7 & RSc0868 & R. solanacearum & & GMI1000 & NP_518989 \\
\hline 16 & XopJ & & X.campestris & vesicatoria & $85-10$ & CAJ23833 \\
\hline 17 & Brg14 & RSp0572 & R. solanacearum & & GMI1000 & NP_522133 \\
\hline 18 & НорАB1 & & P.syringae & glycinea & & AJ439728 \\
\hline 18 & НорАB1 & PSPPHA0127 & P.syringae & phaseolicola & $1448 \mathrm{~A}$ & YP_272234 \\
\hline 18 & HopAB1 & & P.syringae & phaseolicola & 1449B & AAD47203 \\
\hline 18 & НорАВ1 & Psyr4659 & P.syringae & syringae & B728a & AAY39686 \\
\hline 18 & HopAB1 & & P.syringae & savastanoi & ETM317 & CAD29302 \\
\hline 18 & НорАВ3 & HopPmaL & P.syringae & maculicola & ES4326 & AF458391 \\
\hline 18 & НорАВ3 & HolPmaN & P.syringae & maculicola & ES4326 & AF458050 \\
\hline 18 & HopAB3* & PSPPH2294 & P.syringae & phaseolicola & 1448A & AAZ35853 \\
\hline
\end{tabular}


Supplemental Material: Annu.Rev.Microbiol. 2006. 60:425-49

doi: 10.1146/annurev.micro.60.080805.142251

Subterfuge and Manipulation: Type III Effector Proteins of Phytopathogenic Backteria

Grant, Fisher, Chang, Mole, and Dangl

\begin{tabular}{|c|c|c|c|c|c|c|}
\hline & Name $^{b}$ & Alt. name & Strain & pv. $^{\mathrm{c}}$ & Isolate & Accession \\
\hline 18 & HopAB2 & PSPTO3087 & P.syringae & tomato & DC3000 & NP_792881 \\
\hline 19 & AvrRps4 & PSPPHA0087 & P.syringae & phaseolicola & $1448 \mathrm{~A}$ & YP_272198 \\
\hline 19 & AvrRps4 & & P.syringae & pisi & 151 & L43559 \\
\hline 19 & HopK1 & PSPTO0044 & P.syringae & tomato & DC3000 & NP 789904 \\
\hline 19 & HopAQ1* & PSPTO4703 & P.syringae & tomato & DC3000 & NP_794448 \\
\hline 19 & ХopO & & X.campestris & vesicatoria & 85-10 & YP_362786 \\
\hline 20 & HopF1 & AvrPphF & P.syringae & phaseolicola & $1449 A$ & AF231452 \\
\hline 20 & HopF2 & & P.syringae & deliphinii & PDDCC529 & AAP23118 \\
\hline 20 & HopF3 & PSPPH3498 & P.syringae & phaseolicola & 1448A & YP_275650 \\
\hline 20 & HopF2 & PSPTO0502 & P.syringae & tomato & DC3000 & NP_790351 \\
\hline 20 & HopAM1 & AvrPpiB & P.syringae & pisi & $870 a$ & X84843 \\
\hline 20 & HopAM1-1 & PSPTO1022 & P.syringae & tomato & DC3000 & NP_790858 \\
\hline 20 & HopAM1-2 & PSPTOA0005 & P.syringae & tomato & DC3000 & NP_808666 \\
\hline 21 & HopAA1 & HopPtoA1 & P.syringae & maculicola & ES4326 & AF458051 \\
\hline 21 & HopAA1 & Psyr1183 & P.syringae & syringae & B728a & YP_234275 \\
\hline 21 & HорАA1-1 & PSPTO1372 & P.syringae & tomato & DC3000 & NP_791199 \\
\hline 21 & HopAA1-2 & PSPTO4718 & P.syringae & tomato & DC3000 & NP_794461 \\
\hline 22 & HорАH1 & Psyr0779 & P.syringae & syringae & B728a & DAA00388 \\
\hline 22 & HopAH2 & PSPPH3036 & P.syringae & phaseolicola & $1448 \mathrm{~A}$ & YP_275213 \\
\hline 22 & HopAH2 & Psyr3123 & P.syringae & syringae & B728a & YP_236193 \\
\hline 22 & HopAH1 & PSPTO0905 & P.syringae & tomato & DC3000 & NP_790744 \\
\hline 23 & HopAF1 & PSPPH1443 & P.syringae & phaseolicola & $1448 \mathrm{~A}$ & YP_273699 \\
\hline 23 & HopAF1 & Psyr381 & P.syringae & syringae & B728a & AAY38843 \\
\hline 23 & HopAF1 & PSPTO1568 & P.syringae & tomato & DC3000 & NP_79139 \\
\hline 24 & НорB1 & & P.syringae & persicae & 5846 & AAN85146 \\
\hline 24 & HорB2 & & P.syringae & syringae & DH015 & AAN85183 \\
\hline 24 & HopB1 & PSPTO1406 & P.syringae & tomato & DC3000 & NP_791233 \\
\hline 25 & HopAS1 & PSPPH4736 & P.syringae & phaseolicola & $1448 \mathrm{~A}$ & YP_276837 \\
\hline 25 & HopAS1 & PSPTO0474 & P.syringae & tomato & DC3000 & NP_790323 \\
\hline 26 & HopAI1 & PSPTO0906 & P.syringae & tomato & DC3000 & NP_790745 \\
\hline 27 & AvrB1 & AvrB & P.syringae & glycinea & race 4 & M21965 \\
\hline 27 & AvrB2 & AvrC & P.syringae & glycinea & race 4 & M22219 \\
\hline 27 & AvrB2 & & P.syringae & phaseolicola & $1448 \mathrm{~A}$ & YP_272229 \\
\hline 27 & AvrB2 & AvrPphC & P.syringae & phaseolicola & NPS3121 & U10377 \\
\hline 27 & AvrB3 & Psyr1219 & P.syringae & syringae & B728a & AF232005 \\
\hline 27 & AvrB3 & HopPsyC2 & P.syringae & syringae & W4N 15 & AAN85189 \\
\hline 27 & XccC & & X.campestris & campestris & ATCC 33913 & ATCC33913 \\
\hline 28 & HopAE1 & PSPPH4326 & P.syringae & phaseolicola & 1448A & YP_276443 \\
\hline 28 & HopAE1 & Psyr4269 & P.syringae & syringae & B728a & DAA00391 \\
\hline 28 & HopW1-1 & HopPmaA & P.syringae & maculicola & ES4326 & AF458040 \\
\hline 28 & HopW1-2 & & P.syringae & maculicola & ES4326 & AY603980 \\
\hline 29 & XccA1 & & X.campestris & campestris & ATCC33913 & AAM43445 \\
\hline 30 & Brg11 & RSc1815 & R. solanacearum & & GMI1000 & CAD15517 \\
\hline 31 & SrfJ & & S. enterica & typhimurium & LT2 & NP_463287 \\
\hline 32 & YopH & & Y. pestis & & KIM & AAC62606 \\
\hline 33 & HopC1 & AvrPpiC & P.syringae & pisi & 299a race 1 & AJ277496 \\
\hline 33 & HopC1 & PSPTO0589 & P.syringae & tomato & DC3000 & NP_790436 \\
\hline 33 & Brg10 & RSc3212 & R. solanacearum & & GMI1000 & NP_521333 \\
\hline 34 & AvrPto1 & Psyr4919 & P.syringae & syringae & B728a & YP_237984 \\
\hline 34 & AvrPto1 & & P.syringae & tomato & JL1065 & L20425 \\
\hline
\end{tabular}


Supplemental Material: Annu.Rev.Microbiol. 2006. 60:425-49

doi: 10.1146/annurev.micro.60.080805.142251

Subterfuge and Manipulation: Type III Effector Proteins of Phytopathogenic Backteria

Grant, Fisher, Chang, Mole, and Dangl

\begin{tabular}{|c|c|c|c|c|c|c|}
\hline & Name ${ }^{b}$ & Alt. name & Strain & pv. $^{\mathrm{c}}$ & Isolate & Accession \\
\hline 34 & AvrPto1 & PSPTO4001 & P.syringae & tomato & DC3000 & NP_793764 \\
\hline 35 & HopM1 & PSPPH1266 & P.syringae & phaseolicola & 1448A & СР000058 \\
\hline 35 & НорМ1 & Psyr1186 & P.syringae & syringae & B728a & YP_234278 \\
\hline 35 & HopM1 & PSPTO1375 & P.syringae & tomato & DC3000 & NP_791202 \\
\hline 36 & HopAG1 & Psyr0778 & P.syringae & syringae & B728a & DAA00387 \\
\hline 37 & AvrRpm1 & & P.syringae & maculicola & M2 & X67808 \\
\hline 37 & AvrRpm1 & & P.syringae & maculicola & M6 & AF359557 \\
\hline 37 & AvrRpm1 & & P.syringae & pisi & race 7 & AJ222647 \\
\hline 37 & AvrRpm1 & AvrPpiA & P.syringae & pisi & race 2 & X67807 \\
\hline 37 & AvrRpm1 & Psyr0738 & P.syringae & syringae & $\mathrm{B} 728 \mathrm{a}$ & AAY35802 \\
\hline 38 & AvrA & & P.syringae & glycinea & race 6 & M15194 \\
\hline 38 & AvrBs1 & & X.campestris & campestris & АТСС33913 & NP_637464 \\
\hline 39 & XopF1 & & X.campestris & vesicatoria & $85-10$ & CAJ22045 \\
\hline 39 & XopF2 & & X.campestris & vesicatoria & $85-10$ & CAJ24621 \\
\hline 40 & XopN & & X.campestris & vesicatoria & $85-10$ & CAJ24623 \\
\hline 41 & hpaA & & X.campestris & campestris & ATCC33913 & NP_636598 \\
\hline 41 & hpaA & & X.axonopodis & campestris & ATCC 33913 & $N P \_640755$ \\
\hline 42 & PopB & RSp0876 & R. solanacearum & & GMI1000 & NP_522437 \\
\hline 42 & SpiC & STY1727 & S. enterica & typhimurium & LT2 & NC_003198 \\
\hline 43 & Brg17 & RSc1349 & R. solanacearum & & GMI1000 & NP_519470 \\
\hline 44 & Brg22 & RSp0193 & R. solanacearum & & GMI1000 & NP_521754 \\
\hline 45 & Brg38 & RSp1031 & R. solanacearum & & GMI1000 & NP 522592 \\
\hline 46 & Brg39 & RSp0732 & R. solanacearum & & GMI1000 & NP 522293 \\
\hline 47 & YopB & & Y.pestis & & $\mathrm{KIM}$ & NP_857753 \\
\hline 48 & YopD & & Y. pestis & & $\mathrm{KIM}$ & NP_857754 \\
\hline 49 & YopE & & Y.pestis & & $\mathrm{KIM}$ & AAC62587 \\
\hline 50 & YopO & & Y.pestis & & KIM & AAN37536 \\
\hline 51 & Yорт & & Y.pestis & & $\mathrm{KIM}$ & NP_857758 \\
\hline 52 & HopA1 & HopA1 & P.syringae & syringae & 61 & AAF71481 \\
\hline 52 & HopA1 & orf2 & P.syringae & syringae & 226 & AAP23133 \\
\hline 52 & HopA2 & HopA2 & P.syringae & atrofaciens & B143 & AAP23114 \\
\hline 52 & HорА2 & HopPsyA & P.syringae & morsprunorum & & AAP23125 \\
\hline 52 & HopA2 & HopPsyB1 & P.syringae & syringae & 464 & AY147017 \\
\hline 52 & НорА2 & HopPsyB2 & P.syringae & syringae & 5D4198 & AAN85150 \\
\hline 52 & НорА2 & HopPsyB1 & P.syringae & syringae & B-301D & AAN85156 \\
\hline 52 & НорА2 & HopPsyB1 & P.syringae & syringae & B5 & AAN85164 \\
\hline 52 & НорА2 & HopPsyB1 & P.syringae & syringae & B6 & AAN85168 \\
\hline 52 & НорA2 & HopPsyB1 & P.syringae & syringae & BK034 & AAN85172 \\
\hline 52 & HopA2 & HopPsyB1 & P.syringae & syringae & PDDCC 3907 & AAN85186 \\
\hline 52 & НорO1-2 & PSPTO4594 & P.syringae & tomato & DC3000 & NP_794345 \\
\hline 52 & HopA1 & PSPTO5354 & P.syringae & tomato & DC3000 & NP_795084 \\
\hline 52 & HopO1-1 & PSPTOA0018 & P.syringae & tomato & DC3000 & NP_808677 \\
\hline 53 & AvrD1 & AvrD & P.syringae & apii & & AF083919 \\
\hline 53 & AvrD1 & AvrD & P.syringae & glycinea & race 0 & U87225 \\
\hline 53 & AvrD1 & AvrD & P.syringae & glycinea & race 1 & U87226 \\
\hline 53 & AvrD1 & AvrD & P.syringae & glycinea & race 3 & U87227 \\
\hline 53 & AvrD1 & AvrD & P.syringae & glycinea & race 6 & U87227 \\
\hline 53 & AvrD1 & AvrD & P.syringae & lacrymans & & L11335 \\
\hline 53 & AvrD1 & AvrD & P.syringae & lacrymans & & L11334 \\
\hline 53 & AvrD1* & PSPPHA0113 & P.syringae & phaseolicola & 1448A & YP_272223 \\
\hline
\end{tabular}


Supplemental Material: Annu.Rev.Microbiol. 2006. 60:425-49

doi: 10.1146/annurev.micro.60.080805.142251

Subterfuge and Manipulation: Type III Effector Proteins of Phytopathogenic Backteria

Grant, Fisher, Chang, Mole, and Dangl

\begin{tabular}{|c|c|c|c|c|c|c|}
\hline & Name $^{b}$ & Alt. name & Strain & pv. $^{\mathrm{c}}$ & Isolate & Accession \\
\hline 53 & AvrD1 & AvrD & P.syringae & phaseolicola & G50 & U87228 \\
\hline 53 & AvrD1 & AvrD & P.syringae & phaseolicola & NPS3121 & L11336 \\
\hline 53 & AvrD1 & AvrD & P.syringae & tomato & РT23 & J03681 \\
\hline 53 & AvrD1 & AvrD & P.syringae & cilantro & & AF083918 \\
\hline 53 & Норт2 & PSPTO4590 & P.syringae & tomato & DC3000 & NP_794341 \\
\hline 53 & НорТ1-2* & PSPTO4593 & P.syringae & tomato & DC3000 & NP_794344 \\
\hline 53 & HopT1-1* & PSPTOA0019 & P.syringae & tomato & DC3000 & AAO59044 \\
\hline $\begin{array}{l}54 \\
54\end{array}$ & $\begin{array}{l}\text { HrpA1 } \\
\text { HopY1 }\end{array}$ & PSPTO0061 & $\begin{array}{l}\text { P.syringae } \\
\text { P.syringae }\end{array}$ & $\begin{array}{l}\text { maculicola } \\
\text { tomato }\end{array}$ & $\begin{array}{c}\text { M2 } \\
\text { DC3000 }\end{array}$ & $\begin{array}{l}\text { AAQ20005. } \\
\text { NP } 789920\end{array}$ \\
\hline 55 & HopN1 & PSPTO1370 & P.syringae & tomato & DC3000 & NP_791197 \\
\hline 55 & HopAL1 & HopPmaK & P.syringae & maculicola & ES4326 & AF458049 \\
\hline 56 & HopS1* & PSPTO4597 & P.syringae & tomato & DC3000 & NP_794348 \\
\hline 56 & HopS2* & PSPTO4588 & P.syringae & tomato & DC3000 & NP_794339 \\
\hline 57 & HopU1* & PSPTO0501 & P.syringae & tomato & DC3000 & NP_ 790350 \\
\hline 58 & HopAD1* & PSPTO4691 & P.syringae & tomato & DC3000 & NP_794440 \\
\hline 59 & HopZ1 & HopPmaD & P.syringae & maculicola & ES4326 & AF458043 \\
\hline 59 & HopZ1 & & P.syringae & syringae & A2 & AAR02168 \\
\hline 59 & HopZ & Hopz' & P.syringae & syringae & B452 & AY147021 \\
\hline 59 & HopZ3 & Psyr1224 & P.syringae & syringae & $\mathrm{B} 728 \mathrm{a}$ & AAF71492 \\
\hline 60 & XopA & & $X$. campestris & vesicatoria & $85-10$ & CAJ22071 \\
\hline 61 & XopC & & $X$. campestris & vesicatoria & $85-10$ & CAJ24112 \\
\hline 62 & XopD & & X.campestris & vesicatoria & $85-10$ & CAJ22068 \\
\hline 63 & XccA2 & & $X$.campestris & campestris & ATCC33913 & AAM41674 \\
\hline 64 & XccB & AvrXccB & X.campestris & campestris & ATCC33913 & AAM42989 \\
\hline 65 & PopA & RSp0877 & R. solanacearum & & GMI1000 & NP_522438 \\
\hline 65 & Brg28 & RSc1356 & R. solanacearum & & GMI1000 & NP_519477 \\
\hline 65 & Brg29 & RSc1357 & R. solanacearum & & GMI1000 & NP_519478 \\
\hline 65 & Brg26 & RSc1800 & R. solanacearum & & GMI1000 & NP_519921 \\
\hline 65 & $\operatorname{Brg} 27$ & RSc1801 & R. solanacearum & & GMI1000 & NP_519922 \\
\hline 65 & Brg25 & RSp0672 & R. solanacearum & & GMI1000 & NP_522233 \\
\hline 66 & $\mathrm{Brg} 36$ & RSc2359 & R. solanacearum & & GMI1000 & NP_ 520480 \\
\hline 67 & Brg40 & RSc3272 & R. solanacearum & & GMI1000 & NP_521391 \\
\hline 68 & Brg41 & RSc1475 & R. solanacearum & & GMI1000 & NP_519596 \\
\hline 69 & Brg46 & RSc0608 & R. solanacearum & & GMI1000 & NP_518729 \\
\hline 70 & Brg47 & RSc3174 & R. solanacearum & & GMI1000 & NP_521295 \\
\hline 71 & Brg16 & RSp0213 & R. solanacearum & & GMI1000 & NP_518334 \\
\hline 72 & Brg21 & RSp0218 & R. solanacearum & & GMI1000 & NP_518339 \\
\hline 73 & Brg23 & RSp0257 & R. solanacearum & & GMI1000 & NP_521818 \\
\hline 74 & Brg31 & RSp0099 & R. solanacearum & & GMI1000 & NP_521660 \\
\hline 74 & Brg32 & RSp0847 & R. solanacearum & & GMI1000 & NP_522408 \\
\hline 74 & Brg30 & RSp1024 & R. solanacearum & & GMI1000 & NP_522585 \\
\hline 75 & Brg33 & RSp0845 & R. solanacearum & & GMI1000 & NP_522406 \\
\hline 76 & Brg34 & RSp0879 & R. solanacearum & & GMI1000 & NP_522440 \\
\hline 77 & Brg35 & RSp0885 & R. solanacearum & & GMI1000 & NP 522446 \\
\hline 78 & Brg37 & RSp1022 & R. solanacearum & & GMI1000 & NP 522583 \\
\hline 79 & Brg43 & RSp1384 & R. solanacearum & & GMI1000 & NP 522943 \\
\hline 80 & $\mathrm{Brg} 44$ & RSp1130 & R. solanacearum & & GMI1000 & NP 522691 \\
\hline 81 & $\mathrm{Brg} 45$ & RSp1460 & R. solanacearum & & GMI1000 & NP 523019 \\
\hline 82 & Brg48 & RSp1388 & R. solanacearum & & GMI1000 & NP 522947 \\
\hline 83 & SseF & & S. enterica & typhimurium & LT2 & NP 460369 \\
\hline
\end{tabular}


Supplemental Material: Annu.Rev.Microbiol. 2006. 60:425-49

doi: 10.1146/annurev.micro.60.080805.142251

Subterfuge and Manipulation: Type III Effector Proteins of Phytopathogenic Backteria

Grant, Fisher, Chang, Mole, and Dangl

\begin{tabular}{|c|c|c|c|c|c|c|}
\hline & Name $^{b}$ & Alt. name & Strain & pv. $^{\mathrm{c}}$ & Isolate & Accession \\
\hline 84 & SseG & & S. enterica & typhimurium & LT2 & NP 460370 \\
\hline 85 & Ssel & & S. enterica & typhimurium & LT2 & AAL19985 \\
\hline 86 & SseJ & & S. enterica & typhimurium & LT2 & AE008772 \\
\hline 87 & SifB & & S. enterica & typhimurium & LT2 & NC_003197 \\
\hline 88 & SopB & & S. enterica & typhimurium & LT2 & NC_003197 \\
\hline 89 & PipB & & S. enterica & typhimurium & LT2 & NC_003197 \\
\hline 90 & SseE & & S. enterica & typhimurium & LT2 & NP_460367 \\
\hline 91 & SifA & & S. enterica & typhimurium & LT2 & AAL20153 \\
\hline 92 & SipA & STY3005 & S. enterica & typhimurium & CT18 & NP_457276 \\
\hline 93 & SipB & STY3008 & S. enterica & typhimurium & CT18 & NP_457279 \\
\hline 94 & SipC & STY3007 & S. enterica & typhimurium & CT18 & NP_457278 \\
\hline 95 & HopAJ1 & HopPmaG & P. syringae & maculicola & ES4326 & AF458045 \\
\hline 95 & HopAJ1* & PSPPH_0763 & P.syringae & phaseolicola & $1448 A$ & AAZ34315.1 \\
\hline 95 & HopAJ2 & PSPPH_4398 & P.syringae & phaseolicola & $1448 \mathrm{~A}$ & AAZ34636.1 \\
\hline 95 & HopAJ2 & Psyr_4357 & P. syringae & syringae & B728a & AAY39387.1 \\
\hline 95 & HopAJ1* & PSPTO0852 & P.syringae & tomato & DC3000 & NP 790692.1 \\
\hline 95 & HopAJ2 & PSPTO4817 & P.syringae & tomato & DC3000 & NP 794551.1 \\
\hline 96 & AvrRpt2 & & P.syringae & tomato & JL1065 & L11355 \\
\hline 97 & HopAR1 & AvrPphB & P.syringae & phaseolicola & race3 & M86401 \\
\hline 98 & HrpZ1 & & P.syringae & carambola & HL1 & AY372185 \\
\hline 98 & HrpZ1 & & P.syringae & apata & & AF092879 \\
\hline 98 & HrpZ1 & & P.syringae & glycinia & race 4 & L41862 \\
\hline 98 & HrpZ1 & & P.syringae & maculicola & M2 & AY325899 \\
\hline 98 & HrpZ1 & & P.syringae & phaseolicola & 1302A race4 & AF268940 \\
\hline 98 & HrpZ1 & PSPPH_1273 & P.syringae & phaseolicola & $1448 \mathrm{~A}$ & AAZ34500.1 \\
\hline 98 & HrpZ1 & & P.syringae & pisi & race 1 & AB018082 \\
\hline 98 & HrpZ1 & & P.syringae & pisi & race 2 & AB018083 \\
\hline 98 & HrpZ1 & & P.syringae & pisi & race 3 & AB018084 \\
\hline 98 & HrpZ1 & & P.syringae & pisi & race 4 & AB018085 \\
\hline 98 & HrpZ1 & & P.syringae & syringae & 61 & L14775 \\
\hline 98 & HrpZ1 & Psyr_1193 & P.syringae & syringae & $\mathrm{B} 728 \mathrm{a}$ & AAY36247.1 \\
\hline 98 & HrpZ1 & & P.syringae & syringae & LOB201 & AB102727 \\
\hline 98 & HrpZ1 & & P.syringae & syringae & NV & AF031667 \\
\hline 98 & HrpZ1 & & P.syringae & tabaci & 6605 & AB049570 \\
\hline 98 & HrpZ1 & PSPTO1382 & P.syringae & tomato & DC3000 & NP_791209 \\
\hline 99 & YscN & & Y. pestis & & KIM & NP_668159 \\
\hline
\end{tabular}

\footnotetext{
Supplemental Table 1 Notes:

${ }^{a}$ Bold font indicates proteins families represented in Figure 3 of the main text.

${ }^{b}$ Proteins marked (*) are not translocated using full length fusions to truncated AvrRpt2 as an assay (1). Note that other members of some of these families are either not tested, or have been demonstrated to be translocated.

${ }^{\mathrm{c}}$ Pathovar
} 
Supplemental Table 1. Analysis: Proteins were identified as type III effectors based on other studies. $P$. syringae were either experimentally confirmed as translocated (1) or identified as type III effector candidates by a variety of computational methods (5). R. solanacearum GMI1000 proteins were found based on their hrp-dependent transcriptional regulation (2). 41 of these are predicted type III effectors and were included along with known $R$. solanacearum type III effector protein PopC. Other sources for type III effector protein sequences were: Salmonella enterica (8); Yersinia pestis (7); Xanthomonas spp. (6) and (3).

\section{LITERATURE CITED}

1. Chang JH, Urbach JM, Law TF, Arnold LW, Hu A, et al. 2005. A highthroughput, near-saturating screen for type III effector genes from Pseudomonas syringae. Proc Natl Acad Sci U S A 102: 2549-54

2. Cunnac S, Occhialini A, Barberis P, Boucher C, Genin S. 2004. Inventory and functional analysis of the large Hrp regulon in Ralstonia solanacearum: identification of novel effector proteins translocated to plant host cells through the type III secretion system. Mol Microbiol 53: 115-28

3. da Silva AC, Ferro JA, Reinach FC, Farah CS, Furlan LR, et al. 2002. Comparison of the genomes of two Xanthomonas pathogens with differing host specificities. Nature 417: 459-63

4. Eisen MB, Spellman PT, Brown PO, Botstein D. 1998. Cluster analysis and display of genome-wide expression patterns. Proc Natl Acad Sci U S A 95: 14863-8

5. Lindeberg M, Stavrinides J, Chang JH, Alfano JR, Collmer A, et al. 2005. Proposed guidelines for a unified nomenclature and phylogenetic analysis of type III Hop effector proteins in the plant pathogen Pseudomonas syringae. Mol Plant Microbe Interact 18: 275-82

6. Roden JA, Belt B, Ross JB, Tachibana T, Vargas J, Mudgett MB. 2004. A genetic screen to isolate type III effectors translocated into pepper cells during Xanthomonas infection. Proc Natl Acad Sci U S A 101: 16624-9

7. Viboud GI, Bliska JB. 2005. Yersinia outer proteins: role in modulation of host cell signaling responses and pathogenesis. Annu Rev Microbiol 59: 69-89

8. Waterman SR, Holden DW. 2003. Functions and effectors of the Salmonella pathogenicity island 2 type III secretion system. Cell Microbiol 5: 501-11 